\title{
Lipid Mediators in the Resolution of Inflammation
}

\author{
Charles N. Serhan ${ }^{1}$, Nan Chiang ${ }^{1}$, Jesmond Dalli ${ }^{1}$, and Bruce D. Levy ${ }^{2}$ \\ ${ }^{1}$ Center for Experimental Therapeutics and Reperfusion Injury, Department of Anesthesiology, Perioperative \\ and Pain Medicine, Harvard Institutes of Medicine, Brigham and Women's Hospital, and Harvard Medical \\ School, Boston, Massachusetts 02115 \\ ${ }^{2}$ Pulmonary and Critical Care Medicine, Department of Internal Medicine, Harvard Institutes of Medicine, \\ Brigham and Women's Hospital and Harvard Medical School, Boston, Massachusetts 02115 \\ Correspondence: cnserhan@zeus.bwh.harvard.edu
}

\begin{abstract}
Mounting of the acute inflammatory response is crucial for host defense and pivotal to the development of chronic inflammation, fibrosis, or abscess formation versus the protective response and the need of the host tissues to return to homeostasis. Within self-limited acute inflammatory exudates, novel families of lipid mediators are identified, named resolvins (Rv), protectins, and maresins, which actively stimulate cardinal signs of resolution, namely, cessation of leukocytic infiltration, counterregulation of proinflammatory mediators, and the uptake of apoptotic neutrophils and cellular debris. The biosynthesis of these resolution-phase mediators in sensu stricto is initiated during lipid-mediator class switching, in which the classic initiators of acute inflammation, prostaglandins and leukotrienes (LTs), switch to produce specialized proresolving mediators (SPMs). In this work, we review recent evidence on the structure and functional roles of these novel lipid mediators of resolution. Together, these show that leukocyte trafficking and temporal spatial signals govern the resolution of self-limited inflammation and stimulate homeostasis.
\end{abstract}

$R^{\infty}$ esolution of an acute inflammatory response is the ideal outcome of this protective host response with return of the tissue to homeostasis (Majno and Joris 2004; Serhan et al. 2010). Lipid mediators are widely appreciated for their important roles in initiating the leukocyte traffic required in host defense (Cotran et al. 1999). These include the classic eicosanoids, prostaglandins (PGs) and leukotrienes (LTs) (Samuelsson et al. 1987; Samuelsson 2012), that stimulate blood flow changes, ede$\mathrm{ma}$, and neutrophil influx to tissues (Flower 2006). Novel resolution-phase mediators that possess potent proresolving actions were identified and named resolvins, protectins, and maresins. Further studies established that these three families as well as lipoxins function together with their aspirin-triggered (AT) forms (collectively termed specialized proresolving mediators [SPMs]) and are biosynthesized during active resolution (Serhan 2004; Serhan and Chiang 2013). The complete stereochemistry of each of the main SPMs is established and their potent actions confirmed via total organic synthesis (Serhan and Petasis 2011). Given increased availability of certain SPMs, a body of

Editors: Ruslan M. Medzhitov

Additional Perspectives on Innate Immunity and Inflammation available at www.cshperspectives.org

Copyright (C) 2015 Cold Spring Harbor Laboratory Press; all rights reserved; doi: 10.1101/cshperspect.a016311

Cite this article as Cold Spring Harb Perspect Biol 2015;7:a016311 
C.N. Serhan et al.

literature emerged that expands their potent proresolving and anti-inflammatory actions and functions originally identified for the SPMs. In this work, we review and update the roles and actions of the SPMs, focusing on recent results with resolvins, protectins, and maresins, in active resolution mechanisms.

Professor Rod Flower of the William Harvey Research Institute, University of London once recited the quotation from Juvenal, a Roman poet, to introduce these new concepts and findings: Quis custodiet ipsos custodes? Who will guard the guards themselves? Hence, this quote is apropos to begin this article focusing on novel chemical mediators of resolution. The guards, the innate immune system phagocytes, certainly require direction (Serhan 2004; Perretti and D'Acquisto 2009) in the form of chemoattractants and chemical signals to appropriately control their function(s) and permit clearance of microbes and cellular debris without tissue injury; the cardinal signs of resolution.

\section{THE ORCHESTRA AND PLAYERS OF THE RESOLUTION PHASE}

In the acute inflammatory response, some chemical signals are from exogenous microbial origins, whereas others are biosynthesized by the host in response to tissue injury and invasion (Cotran et al. 1999; Lawrence et al. 2002; Serhan et al. 2010). Among the chemical signals at the site of an acute inflammatory response (Buckley et al. 2013), those that originate from host essential fatty acids are of particular interest because of their nutritional regulation and the potential to design synthetic mimetics of these naturally optimized molecules (Serhan 2004). Prostaglandins and leukotriene $B_{4}$ are involved in the initiating steps that permit leukocytes and specifically neutrophils to leave, via diapedesis, postcapillary venules (Malawista et al. 2008; Serhan et al. 2010). We focused on mechanisms involved in endogenous anti-inflammation and its resolution (Serhan et al. 2000, 2002; Levy et al. 2001; Serhan 2004). Using a systems approach with LC-MS-MS (liquid chromatography-tandem mass spectrometry) - based lipidomics, in vivo animal models, selflimited resolving inflammatory exudates, and functional assessment with isolated human leukocytes, we identified novel bioactive mediators produced in the resolution phase of acute sterile inflammation (Fig. 1) that activate new proresolving mechanisms (Serhan et al. 2000, 2002; Hong et al. 2003).

Focusing on self-limited resolving exudates also permitted a direct assessment of the host's responses that enables the return to homeostasis. For example, a key bioassay that proved critical in our initial studies focused on stopping human polymorphonuclear neutrophil (PMN) transmigration across vascular endothelial cells and mucosal epithelial cells (Serhan et al. 2000). We focused on neutrophils because they are among the first responders to injury, alarms, and microbial invasion. PMNs, given their high numbers, can amplify inflammation within tissues when inadvertently activated, causing collateral damage. Our hypothesis that endogenous chemical mediators are produced via cellcell interactions within inflammatory exudates (i.e., pus) that control the size, magnitude, and duration of the inflammatory event proved to be the case and is relevant to human translation (Tabas and Glass 2013). Anti-PMN therapy (Takano et al. 1998) that limits tissue damage to control inflammation has increasing appeal. The milestones in resolution of inflammation from observation to active resolution, to new resolution therapeutics first in humans, are reviewed in Serhan $(2011,2014)$. In ancient medical texts of the 11th and 12th centuries, the notion of treating inflammation with resolvents to resolve disease is present (Avicenna, adapted by Laleh Bakhtiar, 1999). However, the concept was apparently lost until the structures and actions of endogenous resolution mediators were elucidated (Serhan et al. 2002). Within exudates resolving to homeostasis, the fundamental cellular processes impacted by SPMs, namely resolvins, protectins, and maresins, proved predictive of their actions in disease models in vivo, because cessation of PMN entry into tissue and the removal of dead PMNs are central to many disease pathologies in which uncontrolled inflammation is involved. 

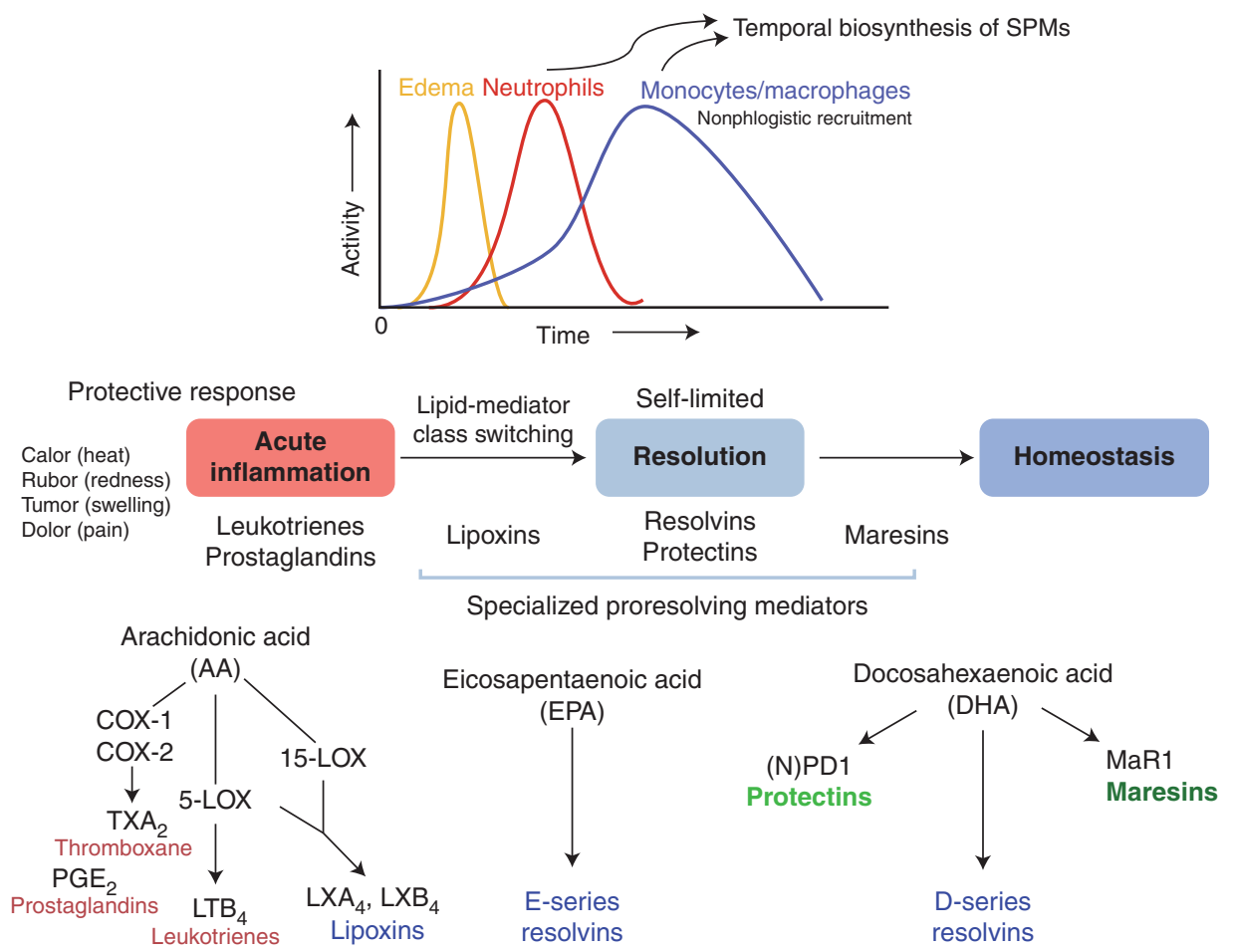

Figure 1. Lipid-mediator biosynthesis in exudate cell traffic in resolution of acute inflammation. Specialized proresolving mediators (SPMs) are generated during inflammation resolution and control the early events in acute inflammation such as edema formation, leukocyte trafficking, and functions (see text).

Metchnikoff observed more than 100 years ago that neutrophils are ingested by tissue macrophages ("big eaters") and that this clearance of neutrophils resolves tissue inflammation (Tauber and Chernyak 1991; Cotran et al. 1999). Subsequent decades of research identified the "go" signals (for example, complement components, cytokines, chemokines, and certain eicosanoids) that promote the recruitment of leukocytes from the blood to the inflamed tissue. Investigators believed that the removal of the inflammatory stimulus prevented the production of chemoattractants that promote leukocyte recruitment and that simple dilution of the chemoattractants prevented further leukocyte cell recruitment and that these passive events brought about the ending of inflammation.

Evidence that the resolution of inflammation is an active process came from our studies on acute self-limiting responses using a sys- tems-based approach (Serhan et al. 2000, 2002; Levy et al. 2001; Hong et al. 2003). Results from these studies showed that, in resolving inflammatory exudates, cell-cell interactions lead to the biosynthesis of active signals that limit further neutrophil recruitment to the tissue (cessation of PMN influx) and enhance the engulfment of apoptotic neutrophils by macrophages, the two cardinal signs of resolution, promoting a return of the tissue to homeostasis. In active resolution, we uncovered a key process coined lipid-mediator class switching in exudates (see Fig. 1). That is, prostaglandins involved in the initiation phase of inflammation activate the translation of mRNAs encoding enzymes (Levy et al. 2001) that are needed for production of proresolvent mediators (lipoxins, resolvins, and protectins) during the resolution phase (Fig. 1). Low-dose aspirin jump-starts the resolution phase by triggering endogenous epimers of these SPMs (Serhan 2007), which is 
C.N. Serhan et al.

shown in animal disease (Chan and Moore 2010; Brancaleone et al. 2013) and in human skin blisters (Morris et al. 2009) and infantile eczema (Wu et al. 2013).

\section{THE ENTRY OF OTHER SUBSTRATES IN RESOLUTION}

We also learned that n-3 essential fatty acids are substrates within these inflammatory resolving exudates for the biosynthesis of potent antiinflammatory and proresolving mediators (Serhan et al. 2002; Hong et al. 2003). Identification of eicosapentaenoic acid (EPA) and docosahexaenoic acid (DHA) as precursors of mediators that activate proresolving mechanisms opened new avenues to consider for appreciating mechanisms underlying uncontrolled inflammation. It is worth noting that a large body of literature addressing the anti-inflammatory impact of EPA and DHA is present (for a recent review, see De Caterina 2011; Calder 2013); yet, the molecular mechanism(s) by which these essential nutrients exert their anti-inflammatory actions remained the subject of debate. DHA and EPA have many known critical functions in mammalian biology. Neither EPA nor DHA is produced by humans to any great extent, requiring their dietary intake (Calder 2013). DHA is an ancient molecule that has functional roles in brain and eye optimized by evolutionary pressure for its physical properties in membranes (Crawford et al. 2013). Uncovering novel chemical mediators that are biosynthesized within self-limited inflammatory responses with exudates in murine systems with functions on individual mammalian and human leukocytes has far-reaching implications (Fig. 1). Along these lines, n-3-derived SPMs are documented in humans in health and disease, including plasma, milk, adipose tissue, and synovial fluid (see Table 1 for details). For recent detailed reviews on resolvins, protectins, and maresins, interested readers are directed to the following: SPM biosynthesis (Bannenberg and Serhan 2010), actions (Recchiuti and Serhan 2012; Serhan and Chiang 2013), and total organic synthesis (Serhan and Petasis 2011). At this point, we address the initial observations of the SPM biosynthesis and activities on phagocytes and in animal models of disease now confirmed in many laboratories (Tables 2 and 3 ).

\section{Endogenous Anti-Inflammation and Proresolution Are Not Equivalent Processes}

Each SPM possesses potent proresolving actions that are fundamental to resolution (Serhan 2004) including limiting or cessation of neutrophil tissue infiltration, counterregulation of chemokines and cytokines (Serhan et al. 2002; Hong et al. 2003), reduction in pain (Xu et al. 2010), and stimulation of macrophagemediated actions, namely, phagocytosis of apoptotic PMNs and bacterial and debris clearance (Table 2) (Schwab et al. 2007; Chiang et al. 2012). The SPMs are multitarget agonists in that they each act on both PMNs and macrophages separately to stimulate resolution. Given this unique proresolving mechanism, resolvins and other SPMs each display potent actions in many animal disease models (Table 3 ). The actions of resolvins and all SPMs are stereochemically selective, reflecting their routes of biosynthesis and underlying their ability to activate receptors (G-protein-coupled receptor [GPCR]) that amplify and transduce their tissue response. Thus, establishing the complete stereochemical assignments for each resolvin, protectin, and maresin (SPM) family was key to confirming their novel leukocyte functions. Given their ability to stimulate resolution of inflammation without systemic immune suppression of host defense (Spite et al. 2009; Oh et al. 2011), we recognize that SPMs stimulate resolution of inflammation and bacterial infection (Serhan 2011; Chiang et al. 2012).

\section{BIOSYNTHESIS, FUNCTION, AND STRUCTURAL ELUCIDATION}

It was essential to confirm the proposed structures and novel potent actions for each of the resolvins and other SPMs (Figs. 2 and 3). To this end, a systematic approach was devised to match endogenous SPMs to those prepared by total organic synthesis (Serhan and Petasis 2011). 
Lipid Mediators in the Resolution of Inflammation

Table 1. Humans and SPMs

\begin{tabular}{|c|c|c|}
\hline SPM & Disease/tissues & Formation \\
\hline \multirow[t]{9}{*}{$\begin{array}{l}\text { Lipoxins and } \\
\text { aspirin- } \\
\text { triggered } \\
\text { lipoxins } \\
\text { (ATLs) }\end{array}$} & Asthma & $\begin{array}{l}\text { Higher urinary ATL levels in aspirin-tolerant asthma than in } \\
\text { aspirin-intolerant asthma (Sanak et al. 2000; Levy et al. 2005; } \\
\text { Yamaguchi et al. 2011) and regulate natural killer (NK) cell and } \\
\text { innate lymphoid cell activation (Barnig et al. 2013; Peebles 2013) }\end{array}$ \\
\hline & Alzheimer's disease (AD) & $\mathrm{LXA}_{4}$ levels are reduced in AD brain and CSF (Wang et al. 2014) \\
\hline & Colitis & $\begin{array}{l}\text { Elevated mucosal } \mathrm{LXA}_{4} \text { promotes remission in individuals with } \\
\text { ulcerative colitis (Vong et al. 2012) }\end{array}$ \\
\hline & Type 2 diabetes & $\begin{array}{l}\text { Increased plasma ATL with intake of pioglitazone (Gutierrez et al. } \\
\text { 2012) }\end{array}$ \\
\hline & Rheumatoid arthritis & $\begin{array}{l}\mathrm{LXA}_{4} \text { in synovial fluid from rheumatoid arthritis patients (Giera } \\
\text { et al. 2012) }\end{array}$ \\
\hline & $\begin{array}{l}\text { Localized aggressive } \\
\text { periodontitis (LAP) }\end{array}$ & $\begin{array}{l}\text { Less } \mathrm{LXA}_{4} \text { in LAP whole blood compared with healthy individuals } \\
\text { (Fredman et al. 2011) }\end{array}$ \\
\hline & Peripheral artery disease & $\begin{array}{l}\text { Plasma levels of ATL are lower in patients with symptomatic } \\
\text { peripheral artery disease (Ho et al. 2010) }\end{array}$ \\
\hline & Adipose tissues & $\begin{array}{l}\text { LXA }_{4} \text { identified in human adipocytes from obese patients (Clària } \\
\text { et al. 2012) }\end{array}$ \\
\hline & Milk & $\begin{array}{l}\text { Lipoxins and resolvins at very high levels in the first month of } \\
\text { lactation (Weiss et al. 2013) }\end{array}$ \\
\hline \multirow[t]{6}{*}{ Resolvins } & Synovial fluid & $\begin{array}{l}\text { RvD5 present in synovial fluid from rheumatoid arthritis patients } \\
\text { (Giera et al. 2012) }\end{array}$ \\
\hline & $\begin{array}{l}\text { Blood (healthy } \\
\text { volunteers) }\end{array}$ & $\begin{array}{l}\text { Plasma RvD1 and RvD2 identified with oral omega-3 } \\
\text { supplementation (Mas et al. 2012; Colas et al. 2014) }\end{array}$ \\
\hline & Adipose tissues & $\begin{array}{l}\text { RvD1 and RvD2 identified in human adipocytes from obese } \\
\text { patients (Clària et al. 2012) }\end{array}$ \\
\hline & Human plasma and milk & $\begin{array}{l}\text { RvE1 identified in human plasma (Psychogios et al. 2011) and } \\
\text { milk (Weiss et al. 2013) }\end{array}$ \\
\hline & Multiple sclerosis & $\begin{array}{l}\text { RvD1 was detected and up-regulated in serum and cerebrospinal } \\
\text { fluid in the highly active group (Pruss et al. 2013) }\end{array}$ \\
\hline & Human IgA nephropathy & $\begin{array}{l}\text { RvE1 identified in patients supplemented with fish oil n-3 } \\
\text { (Zivkovic et al. 2012) }\end{array}$ \\
\hline \multirow[t]{3}{*}{ Protectin } & Asthma & $\begin{array}{l}\text { PD1 in exhaled breath condensates in asthma exacerbation (Levy et } \\
\text { al. 2007); decreased PD1 in eosinophils from patients with severe } \\
\text { asthma compared with healthy individuals (Miyata et al. 2013) }\end{array}$ \\
\hline & Embryonic stem cells & PD1 produced in embryonic stem cells (Yanes et al. 2010) \\
\hline & Multiple sclerosis & $\begin{array}{l}\text { NPD1 was detected in serum and cerebrospinal fluid in the highly } \\
\text { active group (Pruss et al. 2013) }\end{array}$ \\
\hline Maresins & Synovial fluid & $\begin{array}{l}\text { MaR1 identified in synovial fluid from arthritis patients (Giera } \\
\text { et al. 2012) }\end{array}$ \\
\hline
\end{tabular}

This approach was necessary because SPMs are isolated in pure form in only small quantities from exudates (picogram to nanogram range), are locally active, and are inactivated via further metabolism (Arita et al. 2006; Clària et al. 2012). These transient and small quantities preclude direct NMR analysis. The original identification of the D-series resolvins reported the structural elucidation of several distinct bioactive structures that stopped PMN influx and migration, denoted resolvin D1 through resolvin D6, from resolving self-limited murine exudates. Their biosynthetic pathway(s) were established with isolated human leukocytes (Figs. 2 and 3), and potent in vivo actions were determined in murine (Table 3) as well as human inflammation (Ser- 
C.N. Serhan et al.

Table 2. Host defense: Enhanced phagocytosis and the roles of SPMs

\begin{tabular}{|c|c|c|c|}
\hline & Phagocytosis in vivo & PMN & Macrophages \\
\hline $\begin{array}{l}\mathrm{LXA}_{4} \\
\text { ATL }\end{array}$ & $\begin{array}{l}\text { STZ (Schwab et al. 2007) } \\
\text { Apop PMN (El Kebir et al. } \\
\text { 2009) } \\
\text { Escherichia coli (El Kebir et al. } \\
\text { 2009) } \\
\text { Multimicrobial sepsis/CLP } \\
\text { (Walker et al. 2011) }\end{array}$ & & $\begin{array}{l}\text { Apop PMN (Godson et al. 2000; Schwab et al. } \\
\text { 2007) } \\
\text { Serum-treated zymosan (Schwab et al. 2007) } \\
\text { Latex beads (Schwab et al. 2007) } \\
\text { E. coli (Prescott and McKay 2011) }\end{array}$ \\
\hline RvE1 & $\begin{array}{l}\text { STZ (Schwab et al. 2007) } \\
\text { HSV-1 (Rajasagi et al. 2011) } \\
\text { E. coli (Seki et al. 2010; } \\
\quad \text { El Kebir et al. 2012) }\end{array}$ & $\begin{array}{l}\text { Candida albicans } \\
\text { (Haas-Stapleton } \\
\text { et al. 2007) }\end{array}$ & $\begin{array}{l}\text { Apop PMN (Schwab et al. 2007; Oh et al. 2011) } \\
\text { Serum-treated zymosan (Schwab et al. 2007; } \\
\quad \text { Ohira et al. 2010; Oh et al. 2011) } \\
\text { Latex beads (Schwab et al. 2007) } \\
\text { E. coli (Oh et al. 2011) }\end{array}$ \\
\hline 18S-RvE1 & & & $\begin{array}{l}\text { Apop PMN (Oh et al. 2011) } \\
\text { Serum-treated zymosan (Oh et al. 2011) } \\
\text { E. coli (Oh et al. 2011) }\end{array}$ \\
\hline RvE2 & & & Serum-treated zymosan (Oh et al. 2011) \\
\hline PD1 & $\begin{array}{l}\text { STZ (Schwab et al. 2007) } \\
\text { Apop PMN (El Kebir et al. } \\
\quad 2009 \text { ) } \\
\text { E. coli (Chiang et al. 2012) }\end{array}$ & $\begin{array}{l}\text { E. coli (Chiang } \\
\text { et al. 2012) }\end{array}$ & $\begin{array}{l}\text { Serum-treated zymosan (Schwab et al. 2007) } \\
\text { Apop PMN (Schwab et al. 2007) } \\
\text { Latex beads (Schwab et al. 2007) } \\
\text { E. coli (Chiang et al. 2012) }\end{array}$ \\
\hline RvD1 & $\begin{array}{l}\text { E. coli (Chiang et al. 2012) } \\
\text { Apop PMN (Hsiao et al. 2013) }\end{array}$ & $\begin{array}{l}\text { E. coli (Chiang } \\
\text { et al. 2012) }\end{array}$ & $\begin{array}{l}\text { Serum-treated zymosan (Krishnamoorthy } \\
\text { et al. 2010) } \\
\text { Apop PMN (Krishnamoorthy et al. 2010) } \\
\text { E. coli (Chiang et al. 2012) }\end{array}$ \\
\hline AT-RvD1 & & & $\begin{array}{l}\text { E. coli (Palmer et al. 2011) } \\
\text { IgG-OVA-coated beads (Rogerio et al. 2012) }\end{array}$ \\
\hline $\mathrm{RvD2}$ & $\begin{array}{l}\text { Multimicrobial sepsis/CLP } \\
\text { (Spite et al. 2009) }\end{array}$ & $\begin{array}{l}\text { E. coli (Spite et al. } \\
\text { 2009) }\end{array}$ & Serum-treated zymosan (Spite et al. 2009) \\
\hline $\begin{array}{l}\text { RvD3 } \\
\text { AT-RvD3 }\end{array}$ & & & $\begin{array}{l}\text { Serum-treated zymosan (Dalli et al. 2013a) } \\
\text { Apop PMN }\end{array}$ \\
\hline RvD5 & E. coli (Chiang et al. 2012) & $\begin{array}{l}\text { E. coli (Chiang } \\
\text { et al. 2012) }\end{array}$ & E. coli (Chiang et al. 2012) \\
\hline $\begin{array}{l}\mathrm{MaR} 1 \\
\mathrm{MaR} 2\end{array}$ & & & $\begin{array}{l}\text { Serum-treated zymosan (Serhan et al. 2009) } \\
\text { Apop PMN (Serhan et al. 2012; Deng et al. } \\
\text { 2014) }\end{array}$ \\
\hline
\end{tabular}

ATL, aspirin-triggered lipoxins; STZ, serum-treated zymosan; CLP, common lymphoid progenitors.

han et al. 2002; Morris et al. 2009; Wu et al. 2009, 2013).

Recently, the stereochemical structures of resolvin $\mathrm{D} 1$ (RvD1; 7S,8R,17S-trihydroxy-4Z, $9 E, 11 E, 13 Z, 15 E, 19 Z$-docosahexaenoic acid), its AT 17R-epimer (Sun et al. 2007), RvD2 (resolvin D2, $7 S, 16 R, 17 S$-trihydroxy- $4 Z, 8 E, 10 Z$, $12 E, 14 E, 19 Z$-docosahexaenoic acid) (Spite et al. 2009), AT-protectin D1 (PD1; protectin D1/neuroprotectin D1, 10R,17S-dihydroxy-4Z, 7Z,11E,13E,15Z,19Z-docosahexaenoic acid) (Ser- han et al. 2011), and maresin 1 (MaR1; maresin $1,7 R, 14 S$-dihydroxy-docosa- $4 Z, 8 E, 10 E$, $12 Z, 16 Z, 19 Z$-hexaenoic acid) (Serhan et al. 2012) were each assigned, as well as their biosynthetic-related isomers, and several made commercially available.

Recently, we also establish the complete stereochemistry of RvD3 (resolvin D3, 4S,11R,17Strihydroxydocosa-5Z,7E,9E,13Z,15E,19Z-hexaenoic acid) (Fig. 3) and its AT-RvD3 (4S,11R, $17 R$-trihydroxydocosa-5Z,7E,9E,13Z,15E,19Z- 
Table 3. Update on SPM actions in disease models

\begin{tabular}{|c|c|c|}
\hline Disease & SPM & Bioaction \\
\hline $\begin{array}{l}\text { Alzheimer's disease } \\
\text { (AD) }\end{array}$ & RvD1 & $\begin{array}{l}\text { Stimulates phagocytosis of } \mathrm{A} \beta \text { by } \mathrm{AD} \text { macrophages } \\
\text { (Mizwicki et al. 2013) }\end{array}$ \\
\hline Burn wound & RvD2 & $\begin{array}{l}\text { Prevents secondary thrombosis and necrosis (Bohr et al. } \\
\text { 2013) }\end{array}$ \\
\hline Chronic pancreatitis & RvD1 & Reverses allodynia (Feng et al. 2012) \\
\hline Diabetic wounds & RvD1 & Accelerates wound healing (Tang et al. 2013) \\
\hline Dermatitis & RvE1 & Ameliorates dermatitis (Kim et al. 2012) \\
\hline $\begin{array}{l}\text { Pulmonary } \\
\text { inflammation }\end{array}$ & RvE1 & $\begin{array}{l}\text { Promotes apoptosis and accelerates airway resolution (Seki } \\
\text { et al. 2010) }\end{array}$ \\
\hline Peripheral nerve injury & RvE1 & Inhibits neuropathic pain (Xu et al. 2013) \\
\hline Obesity & RvD1, RvD2 & Govern inflammatory tone (Clària et al. 2012) \\
\hline $\begin{array}{l}\text { Allergic airway } \\
\text { response }\end{array}$ & $\begin{array}{l}\text { RvD1, AT-RvD1, RvE1, } \\
\text { PD1 }\end{array}$ & $\begin{array}{l}\text { Promote resolution (Levy et al. 2007; Haworth et al. 2011; } \\
\text { Rogerio et al. 2012) }\end{array}$ \\
\hline $\begin{array}{l}\text { Amyotrophic lateral } \\
\text { sclerosis }\end{array}$ & RvD1 & Inhibits inflammation (Liu et al. 2012) \\
\hline Acute lung injury & AT-RvD1 & Reduces mucosal inflammation (Eickmeier et al. 2013) \\
\hline Fibrosis & RvE1, RvD1 & Inhibit kidney fibrosis (Qu et al. 2012) \\
\hline Bacterial infection & RvD1, RvD5, PD1 & $\begin{array}{l}\text { Increase survival and lower antibiotic requirement } \\
\text { (Chiang et al. 2012) }\end{array}$ \\
\hline Peritonitis & RvD1 & $\begin{array}{l}\text { Limits PMN recruitment and accelerate resolution } \\
\text { (Recchiuti et al. 2011; Norling et al. 2012) }\end{array}$ \\
\hline Dry eye & RvE1 and analog & $\begin{array}{l}\text { Protect from goblet cell loss (de Paiva et al. 2012); improves } \\
\quad \text { tear production ( Li et al. 2010) }\end{array}$ \\
\hline Tissue regeneration & RvE1, MaR1 & $\begin{array}{l}\text { Promote tissue regeneration in planaria (Serhan et al. } \\
\text { 2012) }\end{array}$ \\
\hline Pain & $\begin{array}{l}\text { MaR1, RvD1, AT-RvD1, } \\
\text { RvD2, RvE1 }\end{array}$ & $\begin{array}{l}\text { Control inflammatory pain (Bang et al. 2010, 2012; Xu } \\
\text { et al. 2010; Park et al. 2011; Serhan et al. 2012) }\end{array}$ \\
\hline $\begin{array}{l}\text { Adipose tissue } \\
\text { inflammation }\end{array}$ & RvD1 & $\begin{array}{l}\text { Elicits macrophage polarization and promote resolution } \\
\text { (Titos et al. 2011) }\end{array}$ \\
\hline $\begin{array}{l}\text { Localized aggressive } \\
\text { periodontitis }\end{array}$ & RvE1 & Rescues impaired phagocytosis (Fredman et al. 2011) \\
\hline Colitis & RvD1, RvD2, RvE1 & Prevent colitis (Ishida et al. 2010; Bento et al. 2011) \\
\hline $\begin{array}{l}\text { Temporomandibular } \\
\text { joint inflammation }\end{array}$ & AT-RvD1 & $\begin{array}{l}\text { Limits PMN infiltration to CFA-inflamed TMJ (Norling } \\
\text { et al. 2012) }\end{array}$ \\
\hline Arthritis & AT-RvD1 & Antihyperalgesic (Lima-Garcia et al. 2011) \\
\hline Postoperative pain & RvD1 & Prevents and reduces pain (Huang et al. 2011) \\
\hline $\begin{array}{l}\text { Postsurgical cognitive } \\
\text { decline }\end{array}$ & AT-RvD1 & $\begin{array}{l}\text { Improves postoperative decline and attenuates memory } \\
\text { neuronal dysfunction (Terrando et al. 2013) }\end{array}$ \\
\hline Endotoxin shock & RvD1 & Suppresses septic mediators (Murakami et al. 2011) \\
\hline HSV-keratitis & RvE1 & Controls ocular inflammatory lesions (Rajasagi et al. 2011) \\
\hline Allograft rejection & RvE1 & Preserves organ function (Levy et al. 2011) \\
\hline Heart ischemia & RvE1 & Protects heart against reperfusion injury (Keyes et al. 2010) \\
\hline Bacterial pneumonia & RvE1 & Protects mice from pneumonia (Seki et al. 2010) \\
\hline $\begin{array}{l}\text { Cigarette smoke- } \\
\text { induced lung } \\
\text { inflammation }\end{array}$ & RvD1 & $\begin{array}{l}\text { Promotes M2 macrophages and efferocytosis as well as } \\
\text { accelerates resolution of lung inflammation (Hsiao et al. } \\
\text { 2013) }\end{array}$ \\
\hline $\begin{array}{l}\text { Vascular inflammation } \\
\text { (arterial angioplasty) }\end{array}$ & RvD1 & $\begin{array}{l}\text { Attenuates cell proliferation, leukocyte recruitment, and } \\
\text { neointimal hyperplasia (Miyahara et al. 2013) }\end{array}$ \\
\hline Fibromyalgia & AT-RvD1, RvD2 & $\begin{array}{l}\text { Reduces mechanical allodynia and thermal sensitization } \\
\text { and prevent depressive behavior (Klein et al. 2014) }\end{array}$ \\
\hline Vagotomy & RvD1 & Rescues hyperinflammation (Mirakaj et al. 2014) \\
\hline
\end{tabular}

TMJ, temporomandibular joint. 
C.N. Serhan et al.

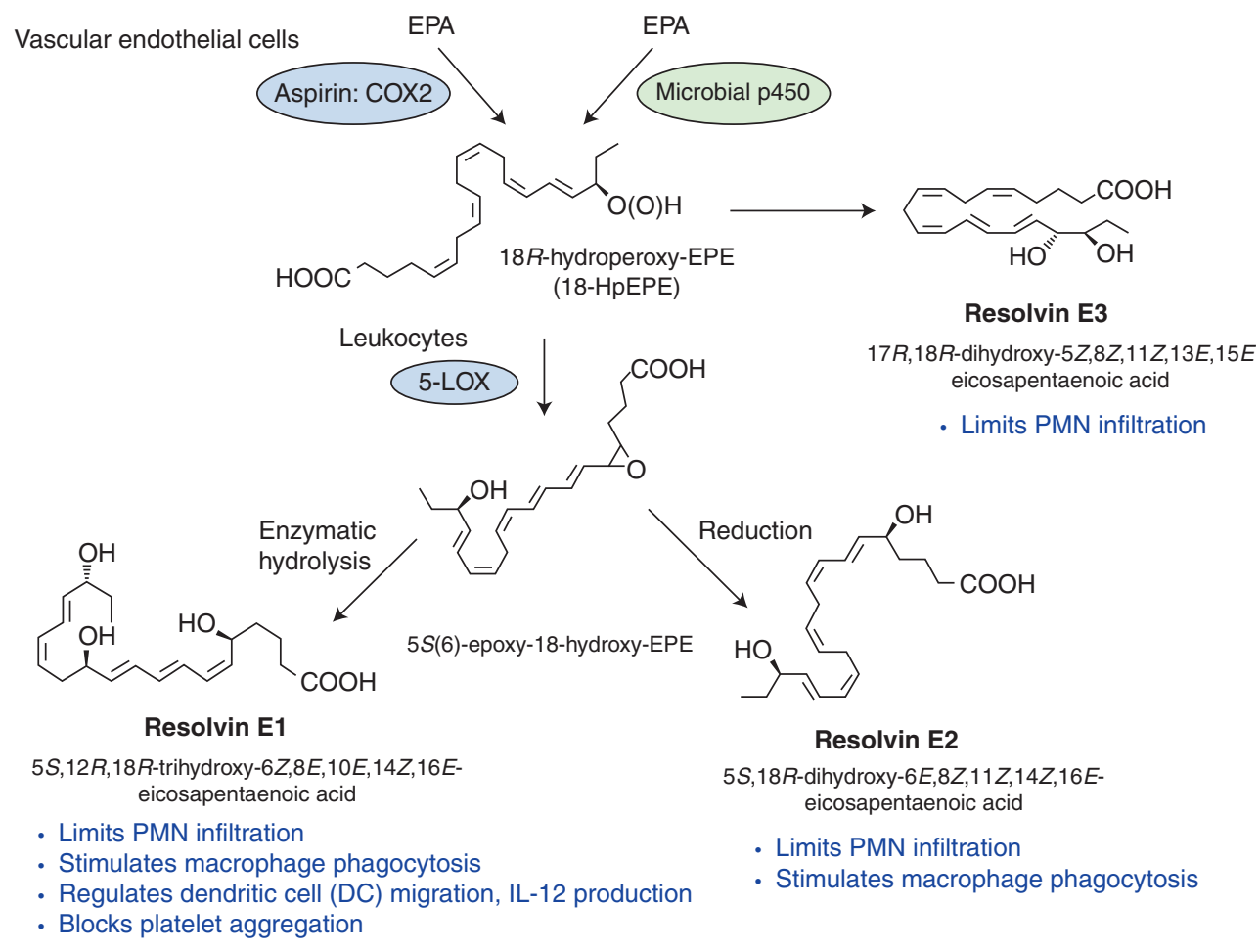

Figure 2. E-series resolvin biosynthesis and major function (see text for details).

hexaenoic acid) natural epimer (Dalli et al. 2013a). Using LC-MS-MS metabololipidomics, we matched the physical properties of $\mathrm{RvD} 3$ with those of synthetic materials possessing the stereochemistry that proved to be $4 S, 11 R, 17 S$ trihydroxydocosa-5Z,7E,9E,13Z,15E,19Z-hexaenoic acid (Fig. 3) and the AT-RvD3, or aspirin-triggered form, matched synthetic $4 S$, $11 R, 17 R$-trihydroxydocosa-5Z,7E, $9 E, 13 Z, 15 E$, 19Z-hexaenoic acid (Dalli et al. 2013a). When administered in vivo, both of these synthetic epimers, at doses as low as $10 \mathrm{pg} / \mathrm{mouse}$, gave potent reduction $(40 \%-50 \%)$ of murine PMN recruitment to sites of inflammation. Both RvD3 and AT-RvD3 increased exudate IL-10 and reduced IL-6 and eicosanoids (Dalli et al. 2013a).

With human leukocytes, RvD3 and AT$\mathrm{RvD} 3$ each potently regulate leukocyte functions enhancing peritoneal macrophage phagocytosis and efferocytosis in a dose-dependent manner while reducing human neutrophil transendothelial migration in response to tumor necrosis factor (TNF)- $\alpha$ (Dalli et al. 2013a). These results establish the complete stereochemistry and confirmed the potent anti-inflammatory and proresolving actions of $\mathrm{RvD} 3$ and its aspirin-triggered epimer denoted AT-RvD3 (see Fig. 3). Moreover, lipid-mediator metabololipidomic profiling of self-resolving exudates also placed RvD3 uniquely within the time course of inflammation resolution to vantage complete resolution, namely, in the later stages (Dalli et al. 2013a).

\section{MARESINS: MACROPHAGE MEDIATORS IN RESOLVING INFLAMMATION}

Recently, we also established the stereochemical assignments for both AT-PD1 (Serhan et al. 2011) and maresin 1 (MaR1) (Serhan et al. 2012). MaR1 produced by human macrophages (MФ) from endogenous docosahexaenoic acid (DHA) matched the stereochemistry of syn- 
Lipid Mediators in the Resolution of Inflammation

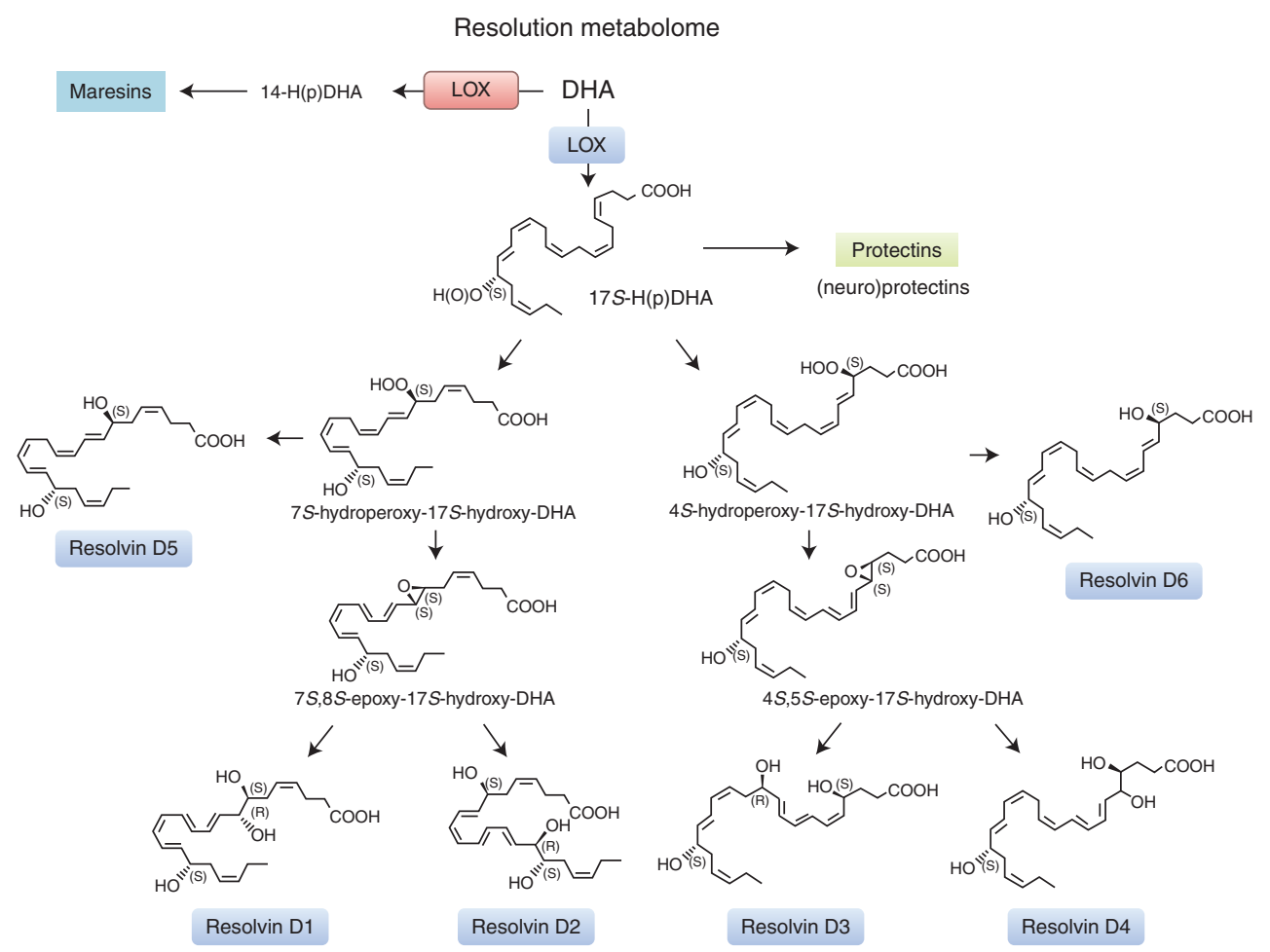

Figure 3. D-series resolvin biosynthesis. The complete stereochemistry of RvD1, RvD2, and RvD3 is established (see Dalli et al. 2013a and text for further details).

thetic $7 R, 14 S$-dihydroxydocosa- $4 Z, 8 E, 10 E, 12 Z$, 16Z,19Z-hexaenoic acid. MaR1 alcohols groups and $Z / E$ geometry of conjugated double bonds were assigned using isomers prepared by total organic synthesis. MaRl's potent defining actions were confirmed with synthetic MaR1 (i.e., limiting neutrophil $[\mathrm{PMN}]$ ) infiltration in murine peritonitis (ng/mouse range) as well as enhancing human macrophage uptake of apoptotic PMNs.

MaR1 is slightly more potent at $1 \mathrm{nM}$ than Resolvin D1 (RvD1) in stimulating human M $\Phi$ efferocytosis, an action not shared by leukotriene $\mathrm{B}_{4}$. Importantly, MaR1 also accelerates surgical regeneration in planaria, increasing the rate of head reappearance. On injury of the planaria (when cut in half), MaR1 is biosynthesized from deuterium-labeled $\left(\mathrm{d}_{5}\right)$-DHA. MaR1 dose-dependently inhibited TRPV1 currents in neurons, blocked capsaicin-induced inward currents $\mathrm{IC}_{50} \approx 0.5 \mathrm{nM}$, and reduced both inflammatory and chemotherapy-induced neuropathic pain in mice (Serhan et al. 2012). Hence, MaR1 has potent actions in regulating inflammation resolution, tissue regeneration, and resolving pain. These findings also suggest that chemical signals are shared in resolution cellular trafficking that is key in tissue regeneration across phyla from worms to humans.

Of special interest, the total organic synthesis of MaR1 was also achieved by Rodriguez and Spur using Sonogashira coupling (2012c), who also reported resolvin D6 (2012a) and organic synthesis of resolvin E2 (2012b) (Figs. 2 and 3). Kobayashi et al. also reported stereoselective total organic synthesis of protectin D1 (Ogawa and Kobayashi 2011), resolvin E2 (Ogawa et al. 2009), and resolvin E1 (Ogawa and Kobayashi 2009). The total organic synthesis of the 18-HEPE, a precursor of E-series resolvins, was also reported (see Fig. 2) (Krishnamurthy et al. 2011). Importantly, the stereoselective actions 
C.N. Serhan et al.

of each SPM proved highly effective in regulating human PMNs and monocytes in microfluidic chambers (Kasuga et al. 2008; Jones et al. 2012), clearly establishing the direct actions on human cells and hence their potential in translational medicine.

\section{MICROPARTICLES IN \\ RESOLUTION AND LEUKOCYTE SUBPOPULATIONS}

With complete stereochemistry of many of the main SPMs established (Figs. 2 and 3), it was possible to carry out lipid-mediator (LM) metabololipidomics profiling via targeted LC-MSMS-based analyses with distinct phagocyte populations, namely, neutrophils (PMNs), apoptotic PMNs, and macrophages (Dalli and Serhan 2012). Efferocytosis increased SPM biosynthesis, including RvD1, RvD2, and RvE2 (resolving E2, 5S,18R-trihydroxy-6E,8Z,11Z,14Z, 16E-eicosapentaenoic acid) (Figs. 2 and 3), which are further elevated by PMN microparticles (Norling et al. 2011). Apoptotic PMNs produced prostaglandin $\mathrm{E}_{2}$, lipoxin $\mathrm{B}_{4}$, and $\mathrm{RvE} 2$, whereas zymosan-stimulated PMNs showed predominantly leukotriene $\mathrm{B}_{4}$ and 20-hydroxy-leukotriene $\mathrm{B}_{4}$, as well as lipoxin biosynthesis pathway marker 5,15-diHETE. Using deuterium-labeled precursors $\left(\mathrm{d}_{8}\right.$-arachidonic acid, $\mathrm{d}_{5}$-eicosapentaenoic acid, and $\mathrm{d}_{5}$-docosahexaenoic acid), apoptotic PMNs and microparticles each contribute to SPM biosynthesis during the process of efferocytosis. Also, M2 macrophage phenotype (Lawrence and Natoli 2011) produces SPMs including MaR1 and $\mathrm{LXA}_{4}$ (lipoxin $\mathrm{A}_{4}$, $5 S, 6 R, 15 S$-trihydroxy-7E,9E,11Z,13E-eicosatetraenoic acid) with lower amounts of $\mathrm{LTB}_{4}$ (leukotriene $\mathrm{B}_{4}, 5 S, 12 R$-dihydroxy- $6 Z, 8 E, 10 E, 14 Z$ eicosatetraenoic acid) and prostaglandin (PG) than the macrophages of the M1 phenotype (Dalli and Serhan 2012). Of interest, the uptake of apoptotic PMNs by both macrophage subtypes led to modulation of their LM profiles and activation of transcellular SPM biosynthesis. These results establish LM signature profiles of human PMNs, apoptotic PMNs, and macrophage subpopulations (Dalli and Serhan 2012). Hence, microparticle regulation of spe- cific endogenous LMs during defined stages of the acute inflammatory process and their dynamic changes in LM signatures are influenced by transcellular biosynthesis between apoptotic cells, microparticles, and macrophages.

\section{RESOLUTION AND INFECTION: WHAT IS THEIR RELATIONSHIP?}

How bacterial infections contribute to active resolution of inflammation is of wide interest. Hence, we focused on exudate leukocyte trafficking and mediator metabololipidomics with murine peritoneal Escherichia coli infections (Chiang et al. 2012) and documented the temporal identification of both proinflammatory (PG and LT) and SPMs. In self-resolving E. coli exudates $\left(10^{5} \mathrm{CFU}\right)$, the dominant SPMs were RvD5 (resolvin D5, 7S,17S-dihydroxy4Z,8E,10Z,13Z,15E,19Z-docosahexaenoic acid) and PD1, which at $12 \mathrm{~h}$ were greater than levels in exudates from higher titer E. coli $\left(10^{7} \mathrm{CFU}\right)$ -infected mice. Of interest, germ-free mice produced endogenous RvD1 and PD1 levels higher than in conventional mice. RvD1 and RvD5 (ng/mouse) each reduced bacterial titers in blood and exudates, E. coli-induced hypothermia, and increased survival.

To translate these to humans, both human PMNs and macrophages were tested with RvD1, RvD5, and PD1, which each directly enhanced phagocytosis of E. coli, and both RvD1 and RvD5 counterregulate a panel of proinflammatory genes, including NF- $\kappa \mathrm{B}$ and TNF- $\alpha$. RvD5 activated the RvD1 receptor GPR32 to enhance phagocytosis. With self-limited E. coli infections, RvD1 and an antibiotic ciprofloxacin accelerated resolution, and each shortened resolution intervals $\left(\mathrm{R}_{i}\right)$. Host-directed RvD1 actions enhanced ciprofloxacin's therapeutic actions. In $10^{7}$ CFU E. coli infections, SPMs (RvD1, RvD5, PD1) together with ciprofloxacin also heightened host antimicrobial responses, enhancing clearance of E. coli in blood and exudates. In skin infections, SPMs stimulated vancomycin clearance of Staphylococcus aureus. Hence, specific SPM are temporally and differentially regulated during infections. They are antiphlogistic, enhance containment, and lower 
Lipid Mediators in the Resolution of Inflammation

antibiotic requirements for bacterial clearance. These endogenous resolution mechanisms are of interest in host defense because initiation of the host response is controlled in part by PG and LT (von Moltke et al. 2012), which when uncontrolled can lead to increased mortality from infection (Chiang et al. 2012), as also observed in zebrafish infections (Tobin et al. 2012). This goes beyond bacteria to viral and fungal infections. Of special interest, PD1 (Fig. 3) produced by the host was identified as a novel antiviral that directly blocks viral replication and increases host survival to influenza viral infection (Baillie and Digard 2013; Morita et al. 2013), which also suggests treating the host as with bacterial infections rather than treating the microbes alone with antibiotics (Chiang et al. 2012). The EPA-derived RvE1 (resolvin E1, $5 S, 12 R, 18 R$-trihydroxy-6Z,8E,10E,14Z,16E-eicosapentaenoic acid) (Fig. 2) also controls fungal infections as observed with Candida albicans (Haas-Stapleton et al. 2007).

\section{GPC RECEPTORS IN RESOLUTION}

We identified two GPCRs for RvD1 on human phagocytes, namely, ALX and GPR32. ALX/ FPR2 is the lipoxin $A_{4}$ receptor, and GPR32 was an orphan receptor. RvD1 displays specific binding and reduces actin polymerization and CD11b on PMNs, as well as stimulates macrophage phagocytosis, an action dependent on ALX and GPR32 (Krishnamoorthy et al. 2010). In addition to RvD1, its AT epimer 17R-RvD1 and stable analog 17-R/S-methyl-RvD1 each dose-dependently activates ALX/FPR2 and GPR32 in GPCR-overexpressing $\beta$-arrestin systems and electric cell-substrate impedance sensing (Krishnamoorthy et al. 2012). Of interest, we showed that RvD5 also activates human GPR32 in the GPR32- $\beta$-arrestin systems, and stimulates macrophage phagocytosis of E. coli in a GPR32dependent manner (Chiang et al. 2012). In addition, RvD3 and AT-RvD3 each activates GPR32, contributing to their proresolving actions in stimulating macrophage uptake of microbial particles (Dalli et al. 2013a).

A specific receptor for RvE1, ChemR23, is closely related to LX and LTreceptors in deduced amino acid sequences. ChemR23 displays specific RvE1 binding and RvE1-dependent signals to activate monocyte, and reduce dendritic cell migration and IL-12 production (Arita et al. 2005a). RvE1-ChemR23 interactions also stimulate macrophage phagocytosis via phosphorylation-signaling pathways including Ribosomal protein S6, a downstream target of the PI3K/ Akt signaling pathway and the Raf/ERK pathway (Ohira et al. 2010). 18S-RvE1 also binds to ChemR23 with increased affinity and potency compared with the R-epimer, but was more rapidly inactivated than RvE1 (Oh et al. 2011). RvE2 is a partial agonist for ChemR23 (Oh et al. 2012). A leukotriene $B_{4}$ receptor, BLT1, also directly interacts with RvE1, which inhibits calcium mobilization, NF- $\mathrm{KB}$ activation in vitro, and PMN infiltration in vivo (Arita et al. 2007). 18S-RvE1 and RvE2 also bind to BLT1 (Oh et al. 2011, 2012). Hence, RvE1 gives celltype-specific actions: It functions as an agonist for ChemR23 on mononuclear and dendritic cells as well as an antagonist for BLT1 signals on PMNs. Recently, ChemR23-dependent actions of RvE1 were confirmed in mouse renal fibrosis (Qu et al. 2012).

\section{Genetically Engineered Mice}

To prepare transgenic (TG) mice for human ALX/FPR2, hALX transgene was placed under control of CD11b promoter that directed receptor expression in myeloid cells (Levy et al. 2002; Devchand et al. 2003). In non-TG littermates, RvD1 as low as $10 \mathrm{ng}$ given together with zymosan, reduced leukocyte numbers by $\sim 38 \%$ at $24 \mathrm{~h}$. This action was further enhanced in ALX-TG mice giving 53\% reduction of leukocytes. Also with RvD1 treatment, PMN numbers in TG mice was 50\% lower than non-TG controls (Krishnamoorthy et al. 2012). We also prepared transgenic mice overexpressing human ChemR23, the RvE1 receptor, on myeloid cells. In these TG mice, RvE1 is 10 -fold more potent in limiting PMN infiltration in zymosan-initiated peritonitis, compared with non-TG littermates. In addition, ligature-induced alveolar bone loss was diminished in ChemR23tg mice (Gao et al. 2013). Local RvE1 treatment of uni- 
C.N. Serhan et al.

form craniotomy in the parietal bone significantly accelerated regeneration of the bone defect, indicating that RvE1 modulates osteoclast differentiation and bone remodeling by direct actions on bone.

In mice deficient in ALX/fpr2 (mouse ortholog of human ALX), the anti-inflammatory actions of RvD1 were dampened. Administration of RvD1 (1 ng/mouse) significantly reduces PMN infiltration in wild-type mice, but not in fpr2-deficient mice. Also in peritoneal exudates, RvD1 activates LX biosynthesis stimulating the production of the anti-inflammatory mediator $\mathrm{LXB}_{4}$ (lipoxin $\mathrm{B}_{4}, 5 S, 14 R, 15 S$-trihydroxy- $6 E, 8 Z, 10 E, 12 E$-eicosatetraenoic acid) and stimulated the biosynthesis of the cyclooxygenase-derived $\mathrm{PGE}_{2}$ (prostaglandin $\mathrm{E}_{2}$, 9oxo-11R,15S-dihydroxy-5Z,13E-prostadienoic acid) while down-regulating production of the proinflammatory $\mathrm{LTB}_{4}$. This regulation of lipid mediator by RvD1 is lost in the fpr2-deficient mice (Norling et al. 2012). These results indicate that RvD1 dampens acute inflammation in part via ALX receptor. Also, 15-epi-LXA 4 interacts with ALX/FPR in vivo controlled by aspirin (Brancaleone et al. 2013). In BLT1 knockout mice, in vivo anti-inflammatory actions of RvE1 were sharply reduced when given at low doses (100 ng i.v.) in peritonitis. In contrast, RvE1 at higher doses (1.0 $\mu \mathrm{g}$ i.v.) significantly reduced PMN infiltration in a BLT1-independent manner (Arita et al. 2007). Hence, RvE1 binds to BLT1 as a partial agonist, serving as a local damper of BLT1 signals on leukocytes along with other receptors (e.g., ChemR23 receptor-mediated counterregulatory actions) to mediate the resolution of inflammation.

\section{MICRO RNAS OF RESOLUTION:}

\section{SPM-RECEPTOR-microRNA CIRCUITS}

RvD1 controls specific miRNA expression in vivo and in vitro (Recchiuti et al. 2011). This panel of miRs, including miR-146b, 208a, and 219 , was temporally regulated during self-limited inflammation and regulated by RvD1 in vivo as well as in a RvD1-GPCR- (ALX and GPR32) dependent manner in human macrophages (Recchiuti et al. 2011). Macrophages overex- pressing miR-219 significantly down-regulate 5-LOX and reduce $\mathrm{LTB}_{4}$. Hence, 5-LOX is a target of miR-219 (Recchiuti et al. 2011). In addition, RvD1 at low dose (10 ng) significantly increases miR-219 in ALX-TG mice, whereas this dose of RvD1 was not effective in non-TG controls (Krishnamoorthy et al. 2012). Additionally, delayed resolution initiated by high-dose zymosan challenges decreases miR-219-5p expression along with higher $\mathrm{LTB}_{4}$ and lower SPMs (Fredman et al. 2012). Therefore, RvD1 initiated a resolution circuit that involves activation of ALX and miR-219.

\section{CAN RESOLVINS AND SPMS REVERSE ONGOING INFLAMMATION IN HUMANS?}

\section{Clinical Development}

An RvE1 analog significantly improved signs and symptoms in a phase 2 clinical trial in patients with dry eye syndrome. This is the first demonstration of clinical efficacy for the novel class of resolvin therapeutics. The phase III clinical trial is now in progress (Safety and Efficacy Study of RX-10045 on the Signs and Symptoms of Dry Eye, identifier NCT00799552; www .clinical trials.gov). The AT 15-epi-LXA 4 ana$\log , 15-R / S$-methyl-LXA 4 , reduced infantile eczema, showing no apparent toxicity or side effects (Wu et al. 2013).

New Uses of SPMs in Animal Disease Models

For an early review and detailed descriptions of initial animal models defining SPM proresolution action, see Serhan 2007. Recently, with conjunctiva goblet cells, both RvD1 and RvE1 reduced $\mathrm{LTD}_{4^{-}}$and histamine-stimulated conjunctival goblet cell secretion (Dartt et al. 2011; Li et al. 2013). RvE1 delivered as its methyl ester in a murine model of dry eye improves the outcome measures of corneal staining and goblet cell density, indicating the potential of resolvins in the treatment of dry eye (de Paiva et al. 2012). In HSV-induced ocular inflammation, RvE1 significantly reduces cornea lesions and angiogenesis as well as T cells and PMNs. These results indicate that RvE1 represents a novel approach 
to control virus-induced diseases (Rajasagi et al. 2011). A recent study showed a phenotype of delayed wound healing in cornea of female mice. Also in human corneal epithelial cells, estradiol reduced 15-LOX type-I and $\mathrm{LXA}_{4}$. $\mathrm{LXA}_{4}$ addition rescues the estradiol-abrogated wound healing, demonstrating gender-specific differences in the corneal repair mediated by the 15LOX-LXA 4 circuit (Wang et al. 2012). In uveitis in rats, bolus intravenous injection of $\mathrm{RvD} 1$ (10-1000 ng/kg) significantly and dose-dependently reduced LPS-induced ocular derangement and PMNs, T-lymphocytes, as well as cytokines within the eye (Settimio et al. 2012).

In localized aggressive periodontitis (LAP) patients, macrophages show reduced phagocytosis. RvE1 rescues impaired phagocytic activity of LAP macrophages (Fredman et al. 2011). Humanized nanoparticles containing 17R-RvD1 or $\mathrm{LXA}_{4}$ analog protect against inflammation in the temporomandibular joint, a model of temporomandibular joint disease (Norling et al. 2011). Exposure of salivary epithelium to TNF- $\alpha$ and/or interferon (IFN)- $\gamma$ alters tight junction integrity, leading to secretory dysfunction. RvD1 (100 ng/mL) rescues TNF$\alpha$-induced tight junction and cytoskeletal disruption, and enhances cell migration and polarity in an ALX-dependent manner. Hence, RvD1 promotes tissue repair in salivary epithelium and restores salivary gland dysfunction associated with Sjögren's syndrome (Odusanwo et al. 2012). In rabbit arterial angioplasty, endogenous biosynthesis of proresolving lipid mediators, including RvD5 and $\mathrm{LXB}_{4}$, was identified in the artery wall. Resolvins also reduce human smooth muscle cell proliferation and attenuate leukocyte recruitment and neointimal hyperplasia in rabbit balloon-injured arteries (Table 3) (Miyahara et al. 2013).

RvE1 promotes resolution in part via reducing IL-23 and IL-6 in allergic airways of mice as well as increasing IFN- $\gamma$ (Haworth et al. 2008). Also, RvE1 regulates natural killer (NK) cell migration and cytotoxicity (Haworth et al. 2011), and $\mathrm{LXA}_{4}$ regulates NK cells and type 2 innate lymphoid cell activation in asthma (Barnig et al. 2013). AT-RvD1 and RvD1 each markedly shorten resolution intervals for lung eosino- philia and reduce select inflammatory peptides and lipid mediators (Rogerio et al. 2012). In acute lung injury, AT-RvD1 improves epithelial and endothelial barrier integrity, decreases airway resistance, and increases epinephrine levels in bronchoalveolar lavage fluid (BALF) (Eickmeier et al. 2013). Of interest, Fat-1 transgenic mice that have increased endogenous lung $n-3$ PUFA (Hudert et al. 2006) also show higher PD1 and RvE1 levels after bronchoprovocative challenge (Bilal et al. 2011). These transgenic mice, which do not require dietary EPA and DHA to maintain high tissue levels, suggest a protective role for endogenous SPMs in allergic airway responses.

Human eosinophils biosynthesize PD1 as one of their main proresolving mediators, and PD1 production by eosinophils is impaired in patients with severe asthma. PD1, in nanomolar concentrations, reduces eosinophil chemotaxis and adhesion molecules (Miyata et al. 2013). In cigarette smoke-induced lung inflammation in the airways of mice, RvD1 protects and reduces PMN infiltration. RvD1 also promotes differentiation of M2 macrophages and efferocytosis in vivo, one of the cardinal signs of resolution. RvD1 also accelerated resolution of lung inflammation, demonstrating potential of SPMs to resolve lung injuries caused by toxicants such as cigarette smoke (Hsiao et al. 2013).

Resolvin D1 and Resolvin E1 potently regulate inflammatory pain (Xu et al. 2010), and intrathecal injections of RvD1 in rats reduces postoperative surgical pain (Huang et al. 2011). Along these lines, RvD1 (100 ng/kg) decreases TNBS-induced mechanical allodynia and blocked cytokine production in spinal dorsal horn (Quan-Xin et al. 2012), and RvD2 (0.01-1 ng) prevents formalin-induced pain. As part of the molecular mechanisms, RvD2, RvE1, and RvD1 differentially regulated transient receptor potential (TRP) channels (Park et al. 2011). AT-RvD1 significantly reverses the thermal hypersensitivity, and knockdown of epidermal TRPV3 blunts these antinociceptive actions (Bang et al. 2012). In arthritis, AT-RvD1 shows marked antihyperalgesia, decreases production of TNF- $\alpha$ and IL-1 $\beta$ in rat hind paw (Lima-Garcia et al. 2011), and RvD1 reduc- 
C.N. Serhan et al.

es neuroinflammation, stimulating phagocytosis of amyloid- $\beta$ (A $\beta)$ by Alzheimer's disease macrophages and inhibits fibrillar $A \beta$-induced apoptosis. These actions are dependent on GPR32 (Mizwicki et al. 2013).

In the original structure elucidation of resolvin E1, PMN infiltration to mouse skin (dorsal air pouch) was used as one of the biossay outcomes (Serhan et al. 2000). In burn models, RvD2 at $25 \mathrm{pg} / \mathrm{g} /$ animal given systemically post burn prevents thrombosis of the deep dermal vasculature, dermal necrosis, and PMN-mediated damage (Bohr et al. 2013). RvD2 restored PMN directionality in this system and increased survival after a second septic challenge (Kurihara et al. 2013). In DNFB-stimulated atopic dermatitis, RvE1 reduces skin lesions, lowers both IL-4 and IFN- $\gamma$, stimulates recruitment of $\mathrm{CD}^{+} \mathrm{T}$ cells, and decreases serum IgE levels (Kim et al. 2012).

In murine models of colitis, systemic RvE1, AT-RvD1, RvD2, or 17R-HDHA (17R-hydroxy4Z,7Z,10Z,13Z,15E,19Z-docosahexaenoic acid) in nanogram ranges improve disease severity, prevent body weight loss, colonic damage, and PMN infiltration as well as lower select colonic cytokines. The results suggest that some of the SPMs have potential in treating inflammatory bowel diseases (Arita et al. 2005b; Bento et al. 2011).

In adipose macrophages, RvD1 stimulates nonphlogistic phagocytosis and reduces macrophage reactive oxygen species production (Titos et al. 2011). In leptin receptor-deficient ( $\mathrm{db} / \mathrm{db})$ mice, RvD1 (2 $\mu \mathrm{g} / \mathrm{kg})$ improves glucose tolerance, decreases fasting blood glucose, and increases adiponectin production and markers of alternatively activated M2 macrophages (Hellmann et al. 2011). Here, $\mathrm{LXA}_{4}$ (1 nM) attenuates adipose inflammation and improves insulin sensitivity in a model of age-associated adipose inflammation (Borgeson et al. 2012). In diabetic wounds, local application of RvD1 accelerates wound closure and reduces accumulation of apoptotic cells in the wounds (Tang et al. 2013). It is noteworthy that in streptozotocin (STZ)-induced diabetes, fat-1 transgenic mice do not develop hyperglycemia and $\beta$-cell destruction compared with wild-type mice.
RvE1 levels are highly increased in these fat-1 mice, emphasizing endogenous roles for RvE1 in diabetes (Bellenger et al. 2011). Thus, select SPMs and their mimetics may be novel approaches to reduce adipose inflammation and insulin resistance, key in type 2 diabetes.

\section{Fibrosis}

In a unilateral ureteric obstruction (UUO)driven murine fibrosis, RvE1 at only $300 \mathrm{ng} /$ day/mouse reduces accumulation of myofibroblasts, deposition of collagen IV, and myofibroblast proliferation. RvE1 ( $\sim 1-30 \mathrm{~nm})$ directly inhibits PDGF-BB-induced proliferation of fibroblasts, an action dependent on ChemR23 receptor expression (Qu et al. 2012).

\section{CONCLUDING REMARKS}

It is now clear from our efforts that pus, specifically contained resolving inflammatory exudates, produced from nutrient essential fatty acids, contains potent molecules that stimulate resolution and the return of tissues to homeostasis. The main families of molecules reviewed herein are the resolvins, protectins, and maresins, which together with the lipoxins and their ATepimeric versions (Serhan 2005) form a larger genus of molecules we denote as SPMs. Each SPM shows temporal and spatial formation dependent functions within contained inflammatory exudates. The key molecules from each of the families, structures, and actions have been confirmed via total organic synthesis, and their complete stereochemistries assigned. Availability of commercial resolvins and lipoxins has led to a recent surge in reports documenting their novel proresolving and anti-inflammatory actions in many disease models, some of which are reviewed here.

Although the resolvins and SPMs are locally produced and act as autacoids to terminate acute inflammatory responses, recent evidence indicates that these molecules can also reach circulating levels, for example, in human peripheral blood (Oh et al. 2011; Mas et al. 2012). These results demonstrating circulating levels of SPMs that are in the concentration 
Lipid Mediators in the Resolution of Inflammation

ranges found for their anti-inflammatory and proresolving actions suggest that the SPMs, in addition to their local production and action, can also influence other organs. In this context, they might be able to signal anti-inflammation in second organs in addition to their target tissue exudates of origin. Hence, it is particularly relevant that resolvins and protectins can reduce neutrophilic infiltration and protect organs in the response to acute second organ ischemia reperfusion injury (Kasuga et al. 2008) and serve as immunoresolvents (Dalli et al. 2013a). Also, high levels of lipoxins and resolvins were recently identified in human breast milk (Weiss et al. 2013) as well as in animal placenta (Jones et al. 2013). These findings raise important new farreaching implications for whether SPMs can play roles in cell traffic associated with organ development as well as regulate acute inflammatory responses around surgical events and tissue regeneration (Pillai et al. 2012; Dalli et al. 2013b). The presence of these proresolving lipid mediators can impact, for example, child development, and could impact diseases such as allergic asthma encountered later in life (Peebles 2013), as they are encountered during development and serve as determinants in later disease pathologies.

With the availability of commercial resolvins, we have also learned that they are effective in reducing inflammation in a wide range of inflammation-associated diseases (Tables 2 and 3), which taken together support the concept that the return of acute inflammatory responses to tissue homeostasis involves the active biosynthesis of proresolving mediators that function as local autacoids. Because the cell types that are responsible for the biosynthesis of SPMs travel within blood within vasculature that interact with the vascular endothelium and mucosal surfaces, their production is ubiquitous throughout the body as is the flow and traffic of leukocytes. Hence, in addition to their temporal and targeted actions within contained inflammatory exudates and their resolution, additional new biological functions of these mediators are likely to unfold in the years ahead, because they are also produced in vital nutrients in mammals such as in human milk, and, thus, SPMs may also impact both physiologic as well as resolving pathophysiologic processes in humans.

\section{ACKNOWLEDGMENTS}

The authors thank Mary Halm Small for expert assistance in manuscript preparation and support from National Institutes of Health Grants P01GM095467 and R01GM38765 (C.N.S.) and R01HL68669 (B.D.L.).

\section{CONFLICT OF INTEREST DISCLOSURE}

Disclosure: C.N.S. and B.D.L. are inventors on patents [resolvins] assigned to $\mathrm{BWH}$ and licensed to Resolvyx Pharmaceuticals. C.N.S. was scientific founder of Resolvyx Pharmaceuticals and owns equity in the company. The interests of C.N.S. and B.D.L. were reviewed and are managed by the Brigham and Women's Hospital and Partners HealthCare in accordance with their conflict of interest policies.

J.D. and N.C. have no financial conflicts of interest to disclose.

\section{REFERENCES}

Arita M, Bianchini F, Aliberti J, Sher A, Chiang N, Hong S, Yang R, Petasis NA, Serhan CN. 2005a. Stereochemical assignment, anti-inflammatory properties, and receptor for the omega-3 lipid mediator resolvin E1. J Exp Med 201: 713-722.

Arita M, Yoshida M, Hong S, Tjonahen E, Glickman JN, Petasis NA, Blumberg RS, Serhan CN. 2005b. Resolvin $\mathrm{E} 1$, an endogenous lipid mediator derived from omega-3 eicosapentaenoic acid, protects against 2,4,6-trinitrobenzene sulfonic acid-induced colitis. Proc Natl Acad Sci 102: $7671-7676$.

Arita M, Oh S, Chonan T, Hong S, Elangovan S, Sun Y-P, Uddin J, Petasis NA, Serhan CN. 2006. Metabolic inactivation of resolvin E1 and stabilization of its anti-inflammatory actions. J Biol Chem 281: 22847-22854.

Arita M, Ohira T, Sun YP, Elangovan S, Chiang N, Serhan CN. 2007. Resolvin E1 selectively interacts with leukotriene $\mathrm{B}_{4}$ receptor BLT1 and ChemR23 to regulate inflammation. J Immunol 178: 3912-3917.

Avicenna (Abu Ali Sina adapted by Lalech Bakhtiar). 1999. The canon of medicine [al-Qanun fi'l-tibb]. Great Books of the Islamic World, Chicago.

Baillie JK, Digard P. 2013. Influenza-Time to target the host? N Engl J Med 369: 191-193.

Bang S, Yoo S, Yang TJ, Cho H, Kim YG, Hwang SW. 2010. Resolvin D1 attenuates activation of sensory transient 
C.N. Serhan et al.

receptor potential channels leading to multiple anti-nociception. Br J Pharmacol 161: 707-720.

Bang S, Yoo S, Yang TJ, Cho H, Hwang SW. 2012. 17(R)resolvin D1 specifically inhibits transient receptor potential ion channel vanilloid 3 leading to peripheral antinociception. Br J Pharmacol 165: 683-692.

Bannenberg G, Serhan CN. 2010. Specialized pro-resolving lipid mediators in the inflammatory response: An update. Biochim Biophys Acta 1801: 1260-1273.

Barnig C, Cernadas M, Dutile S, Liu X, Perrella MA, Kazani S, Wechsler ME, Israel E, Levy BD. 2013. Lipoxin A4 regulates natural killer cell and type 2 innate lymphoid cell activation in asthma. Sci Transl Med 5: 174ra126.

Bellenger J, Bellenger S, Bataille A, Massey KA, Nicolaou A, Rialland M, Tessier C, Kang JX, Narce M. 2011. High pancreatic n-3 fatty acids prevent STZ-induced diabetes in fat-1 mice: Inflammatory pathway inhibition. Diabetes 60: 1090-1099.

Bento AF, Claudino RF, Dutra RC, Marcon R, Calixto JB. 2011. Omega-3 fatty acid-derived mediators $17(\mathrm{R})$-hydroxy docosahexaenoic acid, aspirin-triggered resolvin D1 and resolvin D2 prevent experimental colitis in mice. J Immunol 187: 1957-1969.

Bilal S, Haworth O, Wu L, Weylandt KH, Levy BD, Kang JX. 2011. Fat-1 transgenic mice with elevated omega-3 fatty acids are protected from allergic airway responses. Biochim Biophys Acta 1812: 1164-1169.

Bohr S, Patel SJ, Sarin D, Irimia D, Yarmush ML, Berthiaume F. 2013. Resolvin D2 prevents secondary thrombosis and necrosis in a mouse burn wound model. Wound Repair Regen 21: 35-43.

Borgeson E, McGillicuddy FC, Harford KA, Corrigan N, Higgins DF, Maderna P, Roche HM, Godson C. 2012. Lipoxin A4 attenuates adipose inflammation. FASEB $J$ 26: $4287-4294$.

Brancaleone V, Gobbetti T, Cenac N, le Faouder P, Colom B, Flower RJ, Vergnolle N, Nourshargh S, Perretti M. 2013. A vasculo-protective circuit centered on lipoxin A4 and aspirin-triggered 15-epi-lipoxin A4 operative in murine microcirculation. Blood 122: 608-617.

Buckley CD, Gilroy DW, Serhan CN, Stockinger B, Tak PP. 2013. The resolution of inflammation. Nat Rev Immunol 13: $59-66$

Calder PC. 2013. Omega-3 polyunsaturated fatty acids and inflammatory processes: Nutrition or pharmacology? $\mathrm{Br}$ J Clin Pharmacol 75: 645-662.

Chan MM-Y, Moore AR. 2010. Resolution of inflammation in murine autoimmune arthritis is disrupted by cyclooxygenase-2 inhibition and restored by prostaglandin E2mediated lipoxin A4 production. J Immunol 184: 64186426.

Chiang N, Fredman G, Bäckhed F, Oh SF, Vickery TW, Schmidt BA, Serhan CN. 2012. Infection regulates proresolving mediators that lower antibiotic requirements. Nature 484: 524-528.

Clària J, Dalli J, Yacoubian S, Gao F, Serhan CN. 2012. Resolvin D1 and resolvin D2 govern local inflammatory tone in obese fat. J Immunol 189: 2597-2605.

Colas RA, Shinohara M, Dalli J, Chiang N, Serhan CN. 2014 Identification and signature profiles for pro-resolving and inflammatory lipid mediators in human tissue. $A m$ J Physiol Cell Physiol 307: C39-C54.

Cotran RS, Kumar V, Collins T, ed. 1999. Robbins pathologic basis of disease. W.B. Saunders, Philadelphia.

Crawford MA, Broadhurst CL, Guest M, Nagar A, Wang Y, Ghebremeskel K, Schmidt WF. 2013. A quantum theory for the irreplaceable role of docosahexaenoic acid in neural cell signalling throughout evolution. Prostaglandins Leukot Essent Fatty Acids 88: 5-13.

Dalli J, Serhan CN. 2012. Specific lipid mediator signatures of human phagocytes: Microparticles stimulate macrophage efferocytosis and pro-resolving mediators. Blood 120: e $60-\mathrm{e} 72$.

Dalli J, Winkler JW, Colas RA, Arnardottir H, Cheng CYC, Chiang N, Petasis NA, Serhan CN. 2013a. Resolvin D3 and aspirin-triggered resolvin D3 are potent immunoresolvents. Chem Biol 20: 188-201.

Dalli J, Zhu M, Vlasenko NA, Deng B, Haeggstrom JZ, Petasis NA, Serhan CN. 2013b. The novel 13S,14S-epoxymaresin is converted by human macrophages to maresin 1 (MaR1), inhibits leukotriene A4 hydrolase (LTA4H), and shifts macrophage phenotype. FASEB J 27: 2573-2583.

Dartt DA, Hodges RR, Li D, Shatos MA, Lashkari K, Serhan CN. 2011. Conjunctival goblet cell secretion stimulated by leukotrienes is reduced by resolvins D1 and E1 to promote resolution of inflammation. J Immunol 186: 4455-4466.

De Caterina R. 2011. n-3 fatty acids in cardiovascular disease. N Engl J Med 364: 2439-2450.

Deng B, Wang CW, Arnardottir HH, Li Y, Cheng CY, Dalli J, Serhan CN. 2014. Maresin biosynthesis and identification of maresin 2, a new anti-inflammatory and pro-resolving mediator from human macrophages. PloS ONE 9: e102362.

de Paiva CS, Schwartz CE, Gjorstrup P, Pflugfelder SC. 2012. Resolvin E1 (RX-10001) Reduces corneal epithelial barrier disruption and protects against goblet cell loss in a murine model of dry eye. Cornea 31: 1299-1303.

Devchand PR, Arita M, Hong S, Bannenberg G, Moussignac R-L, Gronert K, Serhan CN. 2003. Human ALX receptor regulates neutrophil recruitment in transgenic mice: Roles in inflammation and host-defense. FASEB J 17: 652-659.

Eickmeier O, Seki H, Haworth O, Hilberath JN, Gao F, Uddin M, Croze RH, Carlo T, Pfeffer MA, Levy BD. 2013 Aspirin-triggered resolvin D1 reduces mucosal inflammation and promotes resolution in a murine model of acute lung injury. Mucosal Immunol 6: 256-266.

El Kebir D, József L, Pan W, Wang L, Petasis NA, Serhan CN, Filep JG. 2009. 15-Epi-lipoxin A4 inhibits myeloperoxidase signaling and enhances resolution of acute lung injury. Am J Respir Crit Care Med 180: 311-319.

El Kebir D, Gjorstrup P, Filep JG. 2012. Resolvin E1 promotes phagocytosis-induced neutrophil apoptosis and accelerates resolution of pulmonary inflammation. Proc Natl Acad Sci 109: 14983-14988.

Feng Q, Feng F, Feng X, Li S, Wang S, Liu Z, Zhang X, Zhao Q, Wang W. 2012. Resolvin D1 reverses chronic pancreatitis-induced mechanical allodynia, phosphorylation of NMDA receptors, and cytokines expression in the thoracic spinal dorsal horn. BMC Gastroenterol 12: 148. 
Flower RJ. 2006. Prostaglandins, bioassay and inflammation. Br J Pharmacol 147: S182-S192.

Fredman G, Oh SF, Ayilavarapu S, Hasturk H, Serhan CN, Van Dyke TE. 2011. Impaired phagocytosis in localized aggressive periodontitis: Rescue by resolvin E1. PLoS ONE 6: e24422.

Fredman G, Li Y, Dalli J, Chiang N, Serhan CN. 2012. Selflimited versus delayed resolution of acute inflammation: Temporal regulation of pro-resolving mediators and microRNA. Sci Rep 2: 639.

Gao L, Faibish D, Fredman G, Herrera BS, Chiang N, Serhan CN, Van Dyke TE, Gyurko R. 2013. Resolvin E1 and chemokine-like receptor 1 mediate bone preservation. $J$ Immunol 190: 689-694.

Giera M, Ioan-Facsinay A, Toes R, Gao F, Dalli J, Deelder AM, Serhan CN, Mayboroda OA. 2012. Lipid and lipid mediator profiling of human synovial fluid in rheumatoid arthritis patients by means of LC-MS/MS. Biochim Biophys Acta 1821: 1415-1424.

Godson C, Mitchell S, Harvey K, Petasis NA, Hogg N, Brady HR. 2000. Cutting edge: Lipoxins rapidly stimulate nonphlogistic phagocytosis of apoptotic neutrophils by monocyte-derived macrophages. J Immunol 164: $1663-$ 1667.

Gutierrez AD, Sathyanarayana P, Konduru S, Ye Y, Birnbaum Y, Bajaj M. 2012. The effect of pioglitazone treatment on 15-epi-lipoxin A4 levels in patients with type 2 diabetes. Atherosclerosis 223: 204-208.

Haas-Stapleton EH, Lu Y, Hong S, Arita M, Favoreto S, Nigam S, Serhan CN, Agabian N. 2007. Candida albicans modulates host defense by biosynthesizing the pro-resolving mediator resolvin E1. PLoS ONE 2: e1316.

Haworth O, Cernadas M, Yang R, Serhan CN, Levy BD. 2008. Resolvin E1 regulates interleukin-23, interferongamma and lipoxin $\mathrm{A}_{4}$ to promote resolution of allergic airway inflammation. Nat Immunol 9: 873-879.

Haworth O, Cernadas M, Levy BD. 2011. NK cells are effectors for resolvin E1 in the timely resolution of allergic airway inflammation. J Immunol 186: 6129-6135.

Hellmann J, Tang Y, Kosuri M, Bhatnagar A, Spite M. 2011. Resolvin D1 decreases adipose tissue macrophage accumulation and improves insulin sensitivity in obese-diabetic mice. FASEB J 25: 2399-2407.

Ho KJ, Spite M, Owens CD, Lancero H, Kroemer AH, Pande R, Creager MA, Serhan CN, Conte MS. 2010. Aspirintriggered lipoxin and resolvin E1 modulate vascular smooth muscle phenotype and correlate with peripheral atherosclerosis. Am J Pathol 177: 2116-2123.

Hong S, Gronert K, Devchand P, Moussignac R-L, Serhan CN. 2003. Novel docosatrienes and 17S-resolvins generated from docosahexaenoic acid in murine brain, human blood and glial cells: Autacoids in anti-inflammation. J Biol Chem 278: 14677-14687.

Hsiao HM, Sapinoro RE, Thatcher TH, Croasdell A, Levy EP, Fulton RA, Olsen KC, Pollock SJ, Serhan CN, Phipps RP, et al. 2013. A novel anti-inflammatory and pro-resolving role for resolvin D1 in acute cigarette smoke-induced lung inflammation. PLoS ONE 8: e58258.

Huang L, Wang C-F, Serhan CN, Strichartz G. 2011. Enduring prevention and transient reduction of post-operative pain by intrathecal resolvin D1. Pain 152: 557-565.
Hudert CA, Weylandt KH, Wang J, Lu Y, Hong S, Dignass A, Serhan CN, Kang JX. 2006. Transgenic mice rich in endogenous n- 3 fatty acids are protected from colitis. Proc Natl Acad Sci 103: 11276-11281.

Ishida T, Yoshida M, Arita M, Nishitani Y, Nishiumi S, Masuda A, Mizuno S, Takagawa T, Morita Y, Kutsumi H, et al. 2010. Resolvin E1, an endogenous lipid derived from eicosapentaenoic acid, prevents dextran sulfate sodiuminduced colitis. Inflamm Bowel Dis 16: 87-95.

Jones CN, Dalli J, Dimisko L, Wong E, Serhan CN, Irimia D. 2012. Microfluidic chambers for monitoring leukocyte trafficking and humanized nano-proresolving medicines interactions. Proc Natl Acad Sci 109: 20560-20565.

Jones ML, Mark PJ, Keelan JA, Barden A, Mas E, Mori TA, Waddell BJ. 2013. Maternal dietary omega-3 fatty acid intake increases resolvin and protectin levels in the rat placenta. J Lipid Res 54: 2247-2254.

Kasuga K, Yang R, Porter TF, Agrawal N, Petasis NA, Irimia D, Toner M, Serhan CN. 2008. Rapid appearance of resolvin precursors in inflammatory exudates: Novel mechanisms in resolution. J Immunol 181: 8677-8687.

Keyes KT, Ye Y, Lin Y, Zhang C, Perez-Polo JR, Gjorstrup P, Birnbaum Y. 2010. Resolvin E1 protects the rat heart against reperfusion injury. Am J Physiol Heart Circ Physiol 299: H153-H164.

Kim TH, Kim GD, Jin YH, Park YS, Park CS. 2012. Omega-3 fatty acid-derived mediator, Resolvin E1, ameliorates 2,4dinitrofluorobenzene-induced atopic dermatitis in NC/ Nga mice. Int Immunopharmacol 14: 384-391.

Klein CP, Sperotto ND, Maciel IS, Leite CE, Souza AH, Campos MM. 2014. Effects of D-series resolvins on behavioral and neurochemical changes in a fibromyalgialike model in mice. Neuropharmacology 86C: 57-66.

Krishnamoorthy S, Recchiuti A, Chiang N, Yacoubian S, Lee C-H, Yang R, Petasis NA, Serhan CN. 2010. Resolvin D1 binds human phagocytes with evidence for pro-resolving receptors. Proc Natl Acad Sci 107: 1660-1665.

Krishnamoorthy S, Recchiuti A, Chiang N, Fredman G, Serhan CN. 2012. Resolvin D1 receptor stereoselectivity and regulation of inflammation and pro-resolving microRNAs. Am J Pathol 180: 2018-2027.

Krishnamurthy VR, Dougherty A, Haller CA, Chaikof EL. 2011. Total synthesis and bioactivity of 18R-hydroxy eicosapentaenoic acid. J Org Chem 76: 5433-5437.

Kurihara T, Jones CN, Yu YM, Fischman AJ, Watada S, Tompkins RG, Fagan SP, Irimia D. 2013. Resolvin D2 restores neutrophil directionality and improves survival after burns. FASEB J 27: 2270-2281.

Lawrence T, Natoli G. 2011. Transcriptional regulation of macrophage polarization: Enabling diversity with identity. Nat Rev Immunol 11: 750-761.

Lawrence T, Willoughby DA, Gilroy DW. 2002. Anti-inflammatory lipid mediators and insights into the resolution of inflammation. Nat Rev Immunol 2: 787-795.

Levy BD, Clish CB, Schmidt B, Gronert K, Serhan CN. 2001. Lipid mediator class switching during acute inflammation: signals in resolution. Nat Immunol 2: 612-619.

Levy BD, De Sanctis GT, Devchand PR, Kim E, Ackerman K, Schmidt BA, Szczeklik W, Drazen JM, Serhan CN. 2002. Multi-pronged inhibition of airway hyper-responsive- 
C.N. Serhan et al.

ness and inflammation by lipoxin $\mathrm{A}_{4}$. Nat Med 8: 1018 1023.

Levy BD, Bonnans C, Silverman ES, Palmer LJ, Marigowda G, Israel E, Severe Asthma Research Program National Heart Lung and Blood Institute. 2005. Diminished lipoxin biosynthesis in severe asthma. Am J Respir Crit Care Med 172: 824-830.

Levy BD, Kohli P, Gotlinger K, Haworth O, Hong S, Kazani S, Israel E, Haley KJ, Serhan CN. 2007. Protectin D1 is generated in asthma and dampens airway inflammation and hyper-responsiveness. J Immunol 178: 496-502.

Levy BD, Zhang QY, Bonnans C, Primo V, Reilly JJ, Perkins DL, Liang Y, Arnaout MA, Nikolic B, Serhan CN. 2011. The endogenous pro-resolving mediators lipoxin $\mathrm{A}_{4}$ and resolvin $\mathrm{E} 1$ preserve organ function in allograft rejection. Prostaglandins Leukot Essent Fatty Acids 84: 43-50.

Li N, He J, Schwartz CE, Gjorstrup P, Bazan HEP. 2010. Resolvin E1 improves tear production and decreases inflammation in a dry eye mouse model. J Ocul Pharmacol Ther 26: 431-439.

Li D, Hodges RR, Jiao J, Carozza RB, Shatos MA, Chiang N, Serhan CN, Dartt DA. 2013. Resolvin D1 and aspirintriggered resolvin D1 regulate histamine-stimulated conjunctival goblet cell secretion. Mucosal Immunol 6: 1119-1130.

Lima-Garcia J, Dutra R, da Silva K, Motta E, Campos M, Calixto J. 2011. The precursor of resolvin D series and aspirin-triggered resolvin D1 display anti-hyperalgesic properties in adjuvant-induced arthritis in rats. $\mathrm{Br} J$ Pharmacol 164: 278-293.

Liu G, Fiala M, Mizwicki MT, Sayre J, Magpantay L, Siani A, Mahanian M, Chattopadhyay M, La Cava A, WiedauPazos M. 2012. Neuronal phagocytosis by inflammatory macrophages in ALS spinal cord: Inhibition of inflammation by resolvin D1. Am J Neurodegener Dis 1: 60-74.

Majno G, Joris I. 2004. Cells, tissues, and disease: Principles of general pathology. Oxford University Press, New York.

Malawista SE, de Boisfleury Chevance A, van Damme J, Serhan CN. 2008. Tonic inhibition of chemotaxis in human plasma. Proc Natl Acad Sci 105: 17949-17954.

Mas E, Croft KD, Zahra P, Barden A, Mori TA. 2012. Resolvins D1, D2, and other mediators of self-limited resolution of inflammation in human blood following n-3 fatty acid supplementation. Clin Chem 58: 1476-1484.

Mirakaj V. Dalli J, Granja T, Rosenberger P, Serhan CN. 2014. Vagus nerve controls resolution and pro-resolving mediators of inflammation. J Exp Med 211: 1037-1048.

Miyahara T, Runge S, Chatterjee A, Chen M, Mottola G, Fitzgerald JM, Serhan CN, Conte MS. 2013. D-series resolvins attenuate vascular smooth muscle cell activation and neointimal hyperplasia following vascular injury. FASEB J 27: 2220-2232.

Miyata J, Fukunaga K, Iwamoto R, Isobe Y, Niimi K, Takamiya R, Takihara T, Tomomatsu K, Suzuki Y, Oguma T, et al. 2013. Dysregulated synthesis of protectin D1 in eosinophils from patients with severe asthma. J Allergy Clin Immunol 131: 353-360.

Mizwicki MT, Liu G, Fiala M, Magpantay L, Sayre J, Siani A, Mahanian M, Weitzman R, Hayden E, Rosenthal MJ, et al. 2013. $1 \alpha, 25$-Dihydroxyvitamin D3 and resolvin D1 retune the balance between amyloid- $\beta$ phagocytosis and inflammation in Alzheimer's disease patients. $\mathrm{J} \mathrm{Alz-}$ heimers Dis 34: 155-170.

Morita M, Kuba K, Ichikawa A, Nakayama M, Katahira J, Iwamoto R, Watanebe T, Sakabe S, Daidoji T, Nakamura S, et al. 2013. The lipid mediator protectin D1 inhibits influenza virus replication and improves severe influenza. Cell 153: 112-125.

Morris T, Stables M, Hobbs A, de Souza P, Colville-Nash P, Warner T, Newson J, Bellingan G, Gilroy DW. 2009. Effects of low-dose aspirin on acute inflammatory responses in humans. J Immunol 183: 2089-2096.

Murakami T, Suzuki K, Tamura H, Nagaoka I. 2011. Suppressive action of resolvin D1 on the production and release of septic mediators in D-galactosamine-sensitized endotoxin shock mice. Exp Ther Med 2: 57-61.

Norling LV, Spite M, Yang R, Flower RJ, Perretti M, Serhan CN. 2011. Cutting edge: Humanized nano-proresolving medicines mimic inflammation-resolution and enhance wound healing. J Immunol 186: 5543-5547.

Norling LV, Dalli J, Flower RJ, Serhan CN, Perretti M. 2012. Resolvin D1 limits polymorphonuclear leukocytes recruitment to inflammatory loci: Receptor dependent actions. Arterioscler Thromb Vasc Biol 32: 1970-1978.

Odusanwo O, Chinthamani S, McCall A, Duffey ME, Baker OJ. 2012. Resolvin D1 prevents TNF- $\alpha$-mediated disruption of salivary epithelial formation. Am J Physiol Cell Physiol 302: C1331-C1345.

Ogawa N, Kobayashi Y. 2009. Total synthesis of resolvin E1. Tetrahedron Lett 50: 6079-6082.

Ogawa N, Kobayashi Y. 2011. Total synthesis of the antiinflammatory and proresolving protectin D1. Tetrahedron Lett 52: 3001-3004.

Ogawa S, Urabe D, Yokokura Y, Arai H, Arita M, Inoue M. 2009. Total synthesis and bioactivity of resolvin E2. Org Lett 11: 3602-3605.

Oh SF, Pillai PS, Recchiuti A, Yang R, Serhan CN. 2011. Proresolving actions and stereoselective biosynthesis of $18 \mathrm{~S}$ E-series resolvins in human leukocytes and murine inflammation. J Clin Invest 121: 569-581.

Oh SF, Dona M, Fredman G, Krishnamoorthy S, Irimia D, Serhan CN. 2012. Resolvin E2 formation and impact in inflammation resolution. J Immunol 188: 4527-4534.

Ohira T, Arita M, Omori K, Recchiuti A, Van Dyke TE, Serhan CN. 2010. Resolvin E1 receptor activation signals phosphorylation and phagocytosis. J Biol Chem 285: 3451-3461.

Palmer CD, Mancuso CJ, Weiss JP, Serhan CN, Guinan EC, Levy O. 2011. 17(R)-Resolvin D1 differentially regulates TLR4-mediated responses of primary human macrophages to purified LPS and live E. coli. J Leukoc Biol 90: 459-470.

Park CK, Lü N, Xu ZZ, Liu T, Serhan CN, Ji RR. 2011. Resolving TRPV1 and TNF- $\alpha$-mediated spinal cord synaptic plasticity and inflammatory pain with neuroprotectin D1. J Neurosci 31: 15072-15085.

Peebles RS Jr. 2013. A new horizon in asthma: Inhibiting ILC function. Sci Transl Med 5: $174 \mathrm{fs} 7$.

Perretti M, D’Acquisto F. 2009. Annexin A1 and glucocorticoids as effectors of the resolution of inflammation. Nat Rev Immunol 9: 62-70. 
Lipid Mediators in the Resolution of Inflammation

Pillai PS, Leeson S, Porter TF, Owens CD, Kim JM, Conte MS, Serhan CN, Gelman S. 2012. Chemical mediators of inflammation and resolution in post-operative abdominal aortic aneurysm patients. Inflammation 35: 98-113.

Prescott D, McKay DM. 2011. Aspirin-triggered lipoxin enhances macrophage phagocytosis of bacteria while inhibiting inflammatory cytokine production. Am J Physiol Gastrointest Liver Physiol 301: G487-G497.

Pruss H, Rosche B, Sullivan AB, Brommer B, Wengert O, Gronert K, Schwab JM. 2013. Proresolution lipid mediators in multiple sclerosis-Differential, disease severitydependent synthesis—A clinical pilot trial. PLoS ONE 8: e55859.

Psychogios N, Hau DD, Peng J, Guo AC, Mandal R, Bouatra S, Sinelnikov I, Krishnamurthy R, Eisner R, Gautam B, et al. 2011. The human serum metabolome. PLoS ONE 6: e16957.

Qu X, Zhang X, Yao J, Song J, Nikolic-Paterson DJ, Li J. 2012. Resolvins E1 and D1 inhibit interstitial fibrosis in the obstructed kidney via inhibition of local fibroblast proliferation. J Pathol 228: 506-519.

Quan-Xin F, Fan F, Xiang-Ying F, Shu-Jun L, Shi-Qi W, Zhao-Xu L, Xu-Jie Z, Qing-Chuan Z, Wei W. 2012. Resolvin D1 reverses chronic pancreatitis-induced mechanical allodynia, phosphorylation of NMDA receptors, and cytokines expression in the thoracic spinal dorsal horn. BMC Gastroenterol 12: 148.

Rajasagi NK, Reddy PBJ, Suryawanshi A, Mulik S, Gjorstrup P, Rouse BT. 2011. Controlling herpes simplex virus-induced ocular inflammatory lesions with the lipid-derived mediator resolvin E1. J Immunol 186: 1735-1746.

Recchiuti A, Serhan CN. 2012. Pro-resolving lipid mediators (SPMs) and their actions in regulating miRNA in novel resolution circuits in inflammation. Front Immun 3: 298.

Recchiuti A, Krishnamoorthy S, Fredman G, Chiang N, Serhan CN. 2011. MicroRNAs in resolution of acute inflammation: Identification of novel resolvin D1-miRNA circuits. FASEB J 25: 544-560.

Rodriguez AR, Spur BW. 2012a. First total synthesis of the anti-inflammatory lipid mediator Resolvin D6. Tetrahedron Lett 53: 86-89.

Rodriguez AR, Spur BW. 2012b. Total synthesis of the antiinflammatory lipid mediator Resolvin E2. Tetrahedron Lett 53: 1912-1915.

Rodriguez AR, Spur BW. 2012c. Total synthesis of the macrophage derived anti-inflammatory lipid mediator Maresin 1. Tetrahedron Lett 53: 4169-4172.

Rogerio AP, Haworth O, Croze R, Oh SF, Uddin M, Carlo T, Pfeffer MA, Priluck R, Serhan CN, Levy BD. 2012. Resolvin D1 and aspirin-triggered resolvin D1 promote resolution of allergic airways responses. J Immunol 189: 1983-1991.

Samuelsson B. 2012. Role of basic science in the development of new medicines: Examples from the eicosanoid field. J Biol Chem 287: 10070-10080.

Samuelsson B, Dahlen SE, Lindgren JA, Rouzer CA, Serhan CN. 1987. Leukotrienes and lipoxins: Structures, biosynthesis, and biological effects. Science 237: 1171-1176.

Sanak M, Levy BD, Clish CB, Chiang N, Gronert K, Mastalerz L, Serhan CN, Szczeklik A. 2000. Aspirin-tolerant asthmatics generate more lipoxins than aspirin-intolerant asthmatics. Eur Respir J 16: 44-49.

Schwab JM, Chiang N, Arita M, Serhan CN. 2007. Resolvin E1 and protectin D1 activate inflammation-resolution programmes. Nature 447: 869-874.

Seki H, Fukunaga K, Arita M, Arai H, Nakanishi H, Taguchi R, Miyasho T, Takamiya R, Asano K, Ishizaka A, et al. 2010. The anti-inflammatory and proresolving mediator resolvin E1 protects mice from bacterial pneumonia and acute lung injury. J Immunol 184: 836-843.

Serhan CN. 2004. A search for endogenous mechanisms of anti-inflammation uncovers novel chemical mediators: Missing links to resolution. Histochem Cell Biol 122: 305-321.

Serhan CN, guest ed. 2005. Special issue on lipoxins and aspirin-triggered lipoxins. Prostaglandins Leukot Essent Fatty Acids 73: 139-321.

Serhan CN. 2007. Resolution phases of inflammation: Novel endogenous anti-inflammatory and pro-resolving lipid mediators and pathways. Annu Rev Immunol 25: $101-$ 137.

Serhan CN. 2011. The resolution of inflammation: The devil in the flask and in the details. FASEB J 25: 1441-1448.

Serhan CN. 2014. Pro-resolving lipid mediators are leads for resolution physiology. Nature 510: 92-101.

Serhan CN, Chiang N. 2013. Resolution phase lipid mediators of inflammation: Agonists of resolution. Curr Opin Pharmacol 13: 632-640.

Serhan CN, Petasis NA. 2011. Resolvins and protectins in inflammation-resolution. Chem Rev 111: 5922-5943.

Serhan CN, Clish CB, Brannon J, Colgan SP, Chiang N, Gronert K. 2000. Novel functional sets of lipid-derived mediators with antiinflammatory actions generated from omega-3 fatty acids via cyclooxygenase 2-nonsteroidal antiinflammatory drugs and transcellular processing. $J$ Exp Med 192: 1197-1204.

Serhan CN, Hong S, Gronert K, Colgan SP, Devchand PR, Mirick G, Moussignac R-L. 2002. Resolvins: A family of bioactive products of omega-3 fatty acid transformation circuits initiated by aspirin treatment that counter proinflammation signals. J Exp Med 196: 1025-1037.

Serhan CN, Yang R, Martinod K, Kasuga K, Pillai PS, Porter TF, Oh SF, Spite M. 2009. Maresins: Novel macrophage mediators with potent anti-inflammatory and pro-resolving actions. J Exp Med 206: 15-23.

Serhan CN, Ward PA, Gilroy DW, ed. 2010. Fundamentals of inflammation. Cambridge University Press, New York.

Serhan CN, Fredman G, Yang R, Karamnov S, Belayev LS, Bazan NG, Zhu M, Winkler JW, Petasis NA. 2011. Novel proresolving aspirin-triggered DHA pathway. Chem Biol 18: $976-987$.

Serhan CN, Dalli J, Karamnov S, Choi A, Park CK, Xu ZZ, Ji RR, Zhu M, Petasis NA. 2012. Macrophage pro-resolving mediator maresin 1 stimulates tissue regeneration and controls pain. FASEB J 26: 1755-1765.

Settimio R, Clara DF, Franca F, Francesca S, Michele D. 2012. Resolvin D1 reduces the immunoinflammatory response of the rat eye following uveitis. Mediators Inflamm 2012: 318621.

Spite M, Norling LV, Summers L, Yang R, Cooper D, Petasis NA, Flower RJ, Perretti M, Serhan CN. 2009. Resolvin D2 
C.N. Serhan et al.

is a potent regulator of leukocytes and controls microbial sepsis. Nature 461: 1287-1291.

Sun Y-P, Oh SF, Uddin J, Yang R, Gotlinger K, Campbell E, Colgan SP, Petasis NA, Serhan CN. 2007. Resolvin D1 and its aspirin-triggered $17 R$ epimer: Stereochemical assignments, anti-inflammatory properties and enzymatic inactivation. J Biol Chem 282: 9323-9334.

Tabas I, Glass CK. 2013. Anti-inflammatory therapy in chronic disease: Challenges and opportunities. Science 339: 166-172.

Takano T, Clish CB, Gronert K, Petasis N, Serhan CN. 1998. Neutrophil-mediated changes in vascular permeability are inhibited by topical application of aspirin-triggered 15-epi-lipoxin $\mathrm{A}_{4}$ and novel lipoxin $\mathrm{B}_{4}$ stable analogues. $J$ Clin Invest 101: 819-826.

Tang Y, Zhang MJ, Hellmann J, Kosuri M, Bhatnagar A, Spite M. 2013. Proresolution therapy for the treatment of delayed healing of diabetic wounds. Diabetes 62: 618-627.

Tauber AI, Chernyak L. 1991. Metchnikoff and the origins of immunology: From metaphor to theory. Oxford University Press, New York.

Terrando N, Gomez-Galan M, Yang T, Carlstrom M, Gustavsson D, Harding RE, Lindskog M, Eriksson LI. 2013. Aspirin-triggered resolvin D1 prevents surgery-induced cognitive decline. FASEB J 27: 3564-3571.

Titos E, Rius B, González-Périz A, López-Vicario C, MoránSalvador E, Martínez-Clemente M, Arroyo V, Clária J. 2011. Resolvin D1 and its precursor docosahexaenoic acid promote resolution of adipose tissue inflammation by elicitying macrophage polarization toward a pro-resolving phenotype. J Immunol 187: 5408-5418.

Tobin DM, Roca FJ, Oh SF, McFarland R, Vickery TW, Ray JP, Ko DC, Zou Y, Bang ND, Chau TT, et al. 2012. Host genotype-specific therapies can optimize the inflammatory response to mycobacterial infections. Cell 148: 434446.

Vong L, Ferraz JG, Dufton N, Panaccione R, Beck PL, Sherman PM, Perretti M, Wallace JL. 2012. Up-regulation of Annexin-Al and lipoxin $\mathrm{A}_{4}$ in individuals with ulcerative colitis may promote mucosal homeostasis. PLoS ONE 7: e39244.

von Moltke J, Trinidad NJ, Moayeri M, Kintzer AF, Wang SB, van Rooijen N, Brown CR, Krantz BA, Leppla SH, Gronert K, et al. 2012. Rapid induction of inflammatory lipid mediators by the inflammasome in vivo. Nature 490: 107-111.

Walker J, Dichter E, Lacorte G, Kerner D, Spur B, Rodriguez A, Yin K. 2011. Lipoxin a4 increases survival by decreas- ing systemic inflammation and bacterial load in sepsis. Shock 36: 410-416.

Wang SB, Hu KM, Seamon KJ, Mani V, Chen Y, Gronert K. 2012. Estrogen negatively regulates epithelial wound healing and protective lipid mediator circuits in the cornea. FASEB J 26: 1506-1516.

Wang X, Zhu M, Hjorth E, Cortés-Toro V, Eyjolfsdottir H, Graff C, Nennesmo I, Palmblad J, Eriksdotter M, Sambamurti K, et al. 2014. Resolution of inflammation is altered in Alzheimer's disease. Alzheimer's Dement doi: 10.1016/ j.jalz.2013.1012.1024.

Weiss GA, Troxler H, Klinke G, Rogler D, Braegger C, Hersberger M. 2013. High levels of anti-inflammatory and pro-resolving lipid mediators lipoxins and resolvins and declining docosahexaenoic acid levels in human milk during the first month of lactation. Lipids Health Dis 12: 89 .

Wu S-H, Liao P-Y, Yin P-L, Zhang Y-M, Dong L. 2009. Elevated expressions of 15-lipoxygenase and lipoxin $\mathrm{A}_{4}$ in children with acute poststreptococcal glomerulonephritis. Am J Pathol 174: 115-122.

Wu SH, Chen XQ, Liu B, Wu HJ, Dong L. 2013. Efficacy and safety of 15(R/S)-methyl-lipoxin $\mathrm{A}_{4}$ in topical treatment of infantile eczema. Br J Dermatol 168: 172-178.

Xu Z-Z, Zhang L, Liu T, Park J-Y, Berta T, Yang R, Serhan CN, Ji R-R. 2010. Resolvins RvE1 and RvD1 attenuate inflammatory pain via central and peripheral actions. Nat Med 16: 592-597.

Xu ZZ, Berta T, Ji RR. 2013. Resolvin E1 inhibits neuropathic pain and spinal cord microglial activation following peripheral nerve injury. J Neuroimmune Pharmacol 8: 37-41.

Yamaguchi H, Higashi N, Mita H, Ono E, Komase Y, Nakagawa T, Miyazawa T, Akiyama K, Taniguchi M. 2011. Urinary concentrations of 15-epimer of lipoxin $\mathrm{A}_{4}$ are lower in patients with aspirin-intolerant compared with aspirin-tolerant asthma. Clin Exp Allergy 41: 1711-1718.

Yanes O, Clark J, Wong DM, Patti GG, Sánchez-Ruiz A, Benton HP, Trauger SA, Desponts C, Ding S, Siuzdak G. 2010. Metabolic oxidation regulates embryonic stem cell differentiation. Nat Chem Biol 6: 411-417.

Zivkovic AM, Yang J, Georgi K, Hegedus C, Nording ML, O'Sullivan A, German JB, Hogg RJ, Weiss RH, Bay C, et al. 2012. Serum oxylipin profiles in IgA nephropathy patients reflect kidney functional alterations. Metabolomics 8: $1102-1113$. 


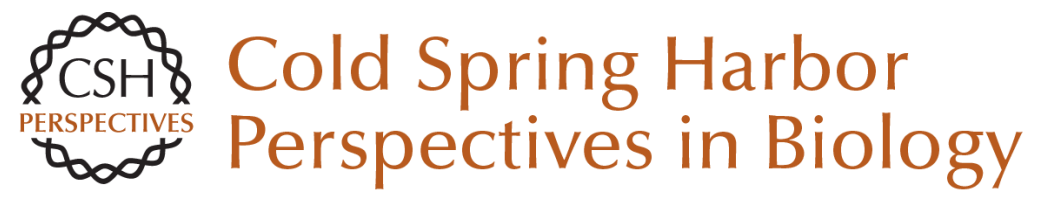

\section{Lipid Mediators in the Resolution of Inflammation}

Charles N. Serhan, Nan Chiang, Jesmond Dalli and Bruce D. Levy

Cold Spring Harb Perspect Biol 2015; doi: 10.1101/cshperspect.a016311 originally published online October 30, 2014

Subject Collection Innate Immunity and Inflammation

Group 2 Innate Lymphoid Cells in Health and Disease

Brian S. Kim and David Artis

Inflammation and the Blood Microvascular

System

Jordan S. Pober and William C. Sessa

Sinusoidal Immunity: Macrophages at the

Lymphohematopoietic Interface

Siamon Gordon, Annette Plüddemann and

Subhankar Mukhopadhyay

Allergic Inflammation--Innately Homeostatic Laurence E. Cheng and Richard M. Locksley

Approaching the Next Revolution? Evolutionary Integration of Neural and Immune Pathogen

Sensing and Response

Kevin J. Tracey

Inflammasomes

Marcel R. de Zoete, Noah W. Palm, Shu Zhu, et al.

IL-6 in Inflammation, Immunity, and Disease

Toshio Tanaka, Masashi Narazaki and Tadamitsu Kishimoto
The Chemokine System in Innate Immunity Caroline L. Sokol and Andrew D. Luster

Microbial Sensing by Toll-Like Receptors and Intracellular Nucleic Acid Sensors Surya Pandey, Taro Kawai and Shizuo Akira

Tumor Necrosis Factor Superfamily in Innate Immunity and Inflammation John Sedý, Vasileios Bekiaris and Carl F. Ware

Emerging Principles Governing Signal Transduction by Pattern-Recognition Receptors Jonathan C. Kagan and Gregory M. Barton

Lipid Mediators in the Resolution of Inflammation Charles N. Serhan, Nan Chiang, Jesmond Dalli, et al.

Transcriptional Control of Inflammatory

Responses

Stephen T. Smale and Gioacchino Natoli

DNA Degradation and Its Defects

Kohki Kawane, Kou Motani and Shigekazu Nagata

For additional articles in this collection, see http://cshperspectives.cshlp.org/cgi/collection/

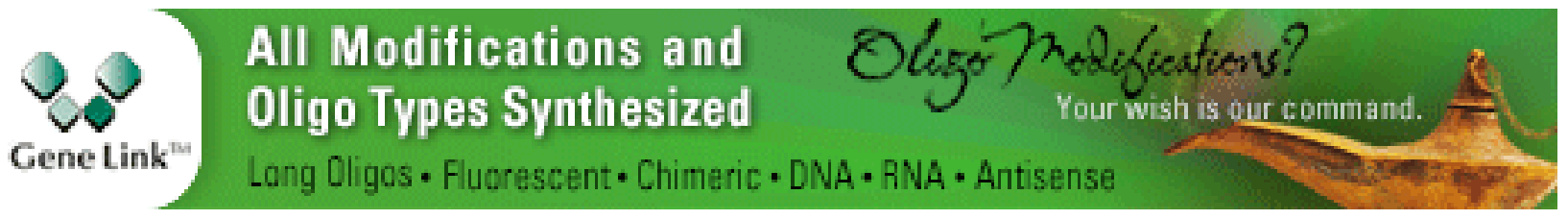

Copyright @ 2015 Cold Spring Harbor Laboratory Press; all rights reserved 